\title{
Dynamics of the Latin Text of the Weichbild: The Sandomierz and the Cracow Versions
}

In order to explain the dynamics of the Latin texts, a number of questions need to be answered: how did the Latin texts evolve before being consolidated in the definitive edition of the Weichbild in Jan Łaski's Statutes? What are the relations between the German and the Latin texts? What are the specific characteristics of the texts in the extant Latin manuscripts? Was there only one, or were there possibly two medieval Latin translations of the Weichbild? In order to answer these questions, it is necessary to make a series of comparisons of both the formal features (the structure) of the text and its contents.

\section{Formal Features of the Latin Texts}

\subsection{The Ordering of Articles in the Latin Texts}

There is a distinct set of formal features that recurs, although not in its entirety, in all Latin texts. First, some of them contain additional regulations in the form of separate provisions or extensive supplements. While additions taken over from the German texts are present in the earliest Latin texts (e.g. the Gniezno Ms; Articles 55, 57, $76 \S 1,3$ and 77), the corpus of the Magdeburg ortyle is a source of important supplementary passages in provisions that echo the German text of the Baworowscy MS (BN 12607) and the Żagań MS (II Q 4). Second, some Latin texts leave out the same articles as does the Wawel manuscript, even though they are included in the Cracow manuscript (Articles 56 and 81, according to the numbering scheme of the Gniezno Ms). Third, some Latin texts skip a provision. The omission can only be detected when the translation is compared to the German text, as in the case of Article 76 (according to the numbering scheme of the Cracow MS BJ 169). Fourth, the Constitution of Courts, which, as a rule, follows the Jewish oath, can appear either in an abridged or an extended form, or can be left out altogether.

Fifth, only a portion of the Latin texts reproduces the articles from the Cracow Ms or the Wawel Ms (BJ 168) consistently in the same order. Notable among the differences are two provisions concerning the gerada and hergewet 
(in the Gniezno Ms, Articles 6o and 61). ${ }^{1}$ In many Latin manuscripts, they were included next to each other. The change of order also concerns Articles 96 and 97, as well as Articles 102 and 103 of the Gniezno Ms. The order in which the articles are arranged is naturally not an argument with the same strength as the presence or absence of an article.

The distribution of features discussed above are presented in Table 8.

TABLE 8 Formal features of the Latin texts of the Weichbild as compared with that of Cracow MS (BJ 169) and Wawel Ms (BJ 168)

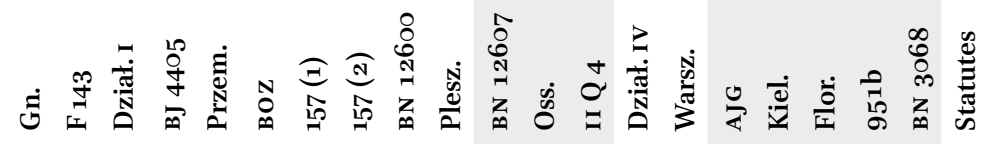

Article 55 (as

designated in Ms Gn.)

Article 57 (as

designated in Ms Gn.)

Article $76 \S_{1}$ and 3 (as

designated in Ms Gn.)

Article 77 (as

designated in Ms Gn.)

No additions from the ortyle

Articles 56, 81 (as designated in MS Gn.)

but not included in

MS BJ 168

Absence of Article 76 of MS BJ 169 in the matching place in the

German text

Shorter version $(+)$, extended version (-), or missing (B) RGV Sequence of Articles $5^{2-54}$ in Ms Gn.

different from that in MS BJ 168

1 For an explanation of terms gerada, hergewet, and principal inheritance, see Chapter 3.4.4. 


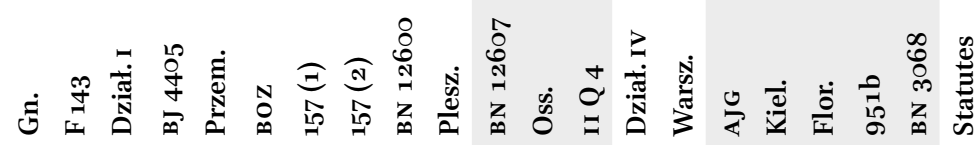

Articles on the gerada and the hergewet positioned next to each other

Sequence of Articles 96-97 in Ms Gn.

different from that in MS BJ 169

Sequence of Articles 102-103 in MS Gn.

different from that in MS BJ 169

Article on the Jewish Oath split up

'o' denotes an absence of an article due to damage to the manuscript; ' \pm ' denotes that the provision on the gerada was included twice, together with the provision on the hergewet, in a slot matching the sequential arrangement of the Cracow Ms.

In effect, taking their formal features as the only criterion, the extant Latin texts can be divided into the following groups:

I) MSs Gn., F 143, Dział. I, BJ 4405, Przem., BOz, Q II 157 (1), Q II 157 (2) and BN 12600 show either all or a clear majority of the features indicated in Table 8. It is no coincidence that some of them (and certainly the Gniezno Ms and the Działyńscy Codex I) are present in manuscripts which include the Sachsenspiegel in its Sandomierz version (versio Sandomiriensis $I$ according to Zygfryd Rymaszewski's classification). The texts in this group do not contain any additions from the ortyle, and in those cases where they do include an extract from the Constitution of Courts after the Jewish oath, it is its abridged version. The texts of this group form the Sandomierz version of the Latin Silesian-Małopolska compilation of the Weichbild, produced originally by Konrad of Sandomierz. It is also worth noting that the author of the Pleszew ms copied less than half of the complete set of provisions.

II) Group II includes texts that lack a number of the features that are characteristic of the Gniezno Ms. The compliance of the Baworowscy MS (BN 12607), the Opatów Ms (Oss.), and the Żagań Ms (II Q 4) with the 
Gniezno manuscript is limited exclusively to the inclusion of provisions that are omitted in the Wawel manuscript. In particular, they contain additions from the ortyle, as does the German text in the Baworowscy Ms and the Żagań ms. The texts of the Działyńscy Codex IV (Dział. IV) and the Warsaw Ms (Warsz.), which also include the Sachsenspiegel in its Sandomierz version (versio Sandomiriensis II according to Zygfryd Rymaszewski's classification), do not contain any ortyle. However, the two manuscripts have some formal features in common with the German text of the Wawel Ms.

III) Group III comprises manuscripts that show some features characteristic of the Gniezno MS and of Group II. The texts of this group are not uniform. Although formally the St Florian ms (Flor.) is not much different from MS Gn., it is in fact a compilation. This is testified by the recurrence of the provision on the gerada in places that match its position in the manuscripts of Groups I and II. The claim that it belongs to the class of compilations will be reinforced in the subsequent discussion. The formal features of the Tomasz of Bydgoszcz's MS (BN 3068) and the Leipzig Ms (951b) leave no doubt that they belong to Group I and Group II, respectively. They, too, contain an abridged version of the Constitution of Courts from Group I, supplementary material from the ortyle, and additional provisions characteristic of the Gniezno Ms Gn. The status of the Częstochowa Ms and the Kielce Ms is unclear. Like the Gniezno Ms, they ignore the ortyle, but contain the provisions that are omitted in the Wawel manuscript. Furthermore, they feature three of the four articles characteristic of the Gniezno manuscript. In the main, the Częstochowa ms and the Kielce ms seem to depend on the text found in the manuscripts of Group I; but, given the presence of numerous features typical of Group II, its domination is by no means total.

Jan Łaski's Statutes deserves special attention, if only because of its official status. For this reason, it will be the focus of the third chapter, but at this stage (analysis of formal features), it can already be said that it is a composite of texts from Group I and II.

While considering the issue of formal features, it is worthwhile to explain the origin of the articles added to the Gniezno MS and other manuscripts in Group I. They are concerned with establishing a proxy for an injured person (Article 55 of MS Gn.), accusations of wounding or murder (Article 57), and the master's liability for his servant's debts (Article $76 \S 1$ and 3 ), as well as liability for damage to property, which was deposited for safe-keeping, handed over for use, including the liability for damages caused by animals (Article 77). Obviously these concerns were anything but petty. The source of Article 55 is 
TABLE 9 Articles $56,57,76$, and 77 of the Weichbild and their origin

\begin{tabular}{|c|c|c|c|c|c|c|c|}
\hline & \multicolumn{2}{|c|}{ Gracow MS (BJ 169) } & \multicolumn{2}{|c|}{ Gniezno Ms (Gn.) } & \multirow{2}{*}{$\begin{array}{l}\text { Baworowscy } \\
\text { Ms (BN } \\
\text { 12607) } \\
\text { Weichbild }\end{array}$} & \multicolumn{2}{|c|}{$\begin{array}{l}\text { Działyńscy Codex IV } \\
\text { (MS Dział. IV) }\end{array}$} \\
\hline & Sachsenspiegel & Weichbild & Sachsenspiegel & Weichbild & & Sachsenspiegel & Weichbild \\
\hline $\begin{array}{l}\text { Numbering } \\
\text { in } \mathrm{MGH}^{\mathrm{a}}\end{array}$ & $\begin{array}{l}\text { Wrocław } \\
\text { version }\end{array}$ & $\begin{array}{l}\text { German } \\
\text { text }\end{array}$ & $\begin{array}{l}\text { Sandomierz } \\
\text { version I }\end{array}$ & Group I & Group II & $\begin{array}{l}\text { Sandomierz } \\
\text { version II }\end{array}$ & $\begin{array}{l}\text { Ms Dział. } \\
\text { IV }\end{array}$ \\
\hline $\begin{array}{l}\text { SSp I } 49 \\
\text { and } 69\end{array}$ & + & - & + & $+[57]$ & - & + & - \\
\hline $\begin{array}{l}\text { SSp III } \\
6 \S 1-3\end{array}$ & + & - & + & $+[76]$ & - & + & - \\
\hline SSp III & + & - & + & $+[77]$ & - & + & - \\
\hline $\begin{array}{l}\text { SSp I } \\
63-65 \S 1\end{array}$ & + & + & - & $+\left[5^{6}\right]$ & + & + & - \\
\hline
\end{tabular}

a Karl A. Eckhard's edition.

Article 72 of Magdeburg's Legal Instructions for Wroctaw of 1261. This regulation was included, in a much amended form, in Article 53 of the Cracow MS; that fact probably prompted the compilers who used that text to go back to its full wording. The text of the other articles falls back on the Sachsenspiegel, as presented in Table 9.

Thus, the texts of Group I reinstate a handful of important Sachsenspiegel provisions (Articles 57, 76, and 77 of the MS Gn.) that are missing in Group II. However, while drawing this conclusion, we need to take note of a string of baffling annotations which begin with a reference to the provisions of the Weichbild in the Gniezno ms Sachsenspiegel at a place where Articles 63, 64, and $65 \S 1$ of SSp I are left out. ${ }^{2}$ The content referred to can be found subsequently in Article $5^{6}$ of the Ius municipale. It is the other way around in the Działyńscy Codex IV, where the reader looking for missing Articles 55, 56, and 57 (as designated in MS Gn.) is referred to the matching section of the Sachsenspiegel. It is worth noting that these articles are also missing in the Wawel MS, where they are replaced with a note in Latin Hoc capitulum continuetur in iure, quod dicitur landrecht.

2 Rymaszewski, Lacińskie teksty Landrechtu Zwierciadta Saskiego w Polsce. Versio Vratislaviensis, versio Sandomiriensis, Łaski (Łódź, 1975), p. 71. 
The presence of a complete set of regulations in the versio Vratislaviensis of the Sachsenspiegel is a well established fact: it was a translation of the entire text of the law code which predates the Silesian-Małopolska compilation of the Weichbild. The availability of the complete text may well have been prompted by Konrad of Sandomierz's decision not to include said regulations from his translation of the Weichbild (i.e. the contents of Article 56). Yet, if we assume that that was his reasoning, why did he expand the size of his Weichbild by adding other articles from the Sachsenspiegel without editing them out from the latter to preserve balance? There is no solution to this inconsistency. As Table 9 shows, the Latin text of the Group II manuscripts follows the German base. Only the author of the Działyńscy Codex IV clears up the redundancies from the Weichbild and restores the complete text of the Sachsenspiegel.

On the diachronic level, the problem of this structural inconsistency can be reformulated in terms of the following alternatives: 1) either Konrad of Sandomierz's extended version came first (Group I), but some of his successors (Group II), after consulting the German base, decided to trim down his text; or 2) it all began with an (original) version of the text in the Cracow MS which was first expanded by Konrad of Sandomierz and later cut back by the author of the Działyńscy Codex IV (which belongs to Group II). This will discussed in the following sections.

\subsection{Summary: The Division of the Latin Wechbild Texts into Groups on the Basis of Their Formal Characteristics}

This comparative analysis, which is based principally on a concordance of the content of the texts collected in Appendix 1 and focused on their general characteristics (content and sequence), shows that one of the aspects of the differentiation of texts is the way in which they were edited. Some texts (Group I) were augmented with provisions from the Sachsenspiegel, which made them more rounded than the texts of another group (designated Group II), which were augmented with Magdeburg judgments (ortyle), which made them more suited for practical use. The thematic rearrangement of the sequence of provisions in Group I indicates that their editor(s) sought to introduce some order into a fragmented text, although its product fell far short of a systematized law code. The analysis has also identified a group of texts in which the two types of augmentation are combined. Now that the manuscript texts have been divided into clearly defined groups and the differentiation can be associated with an intention or purpose, the next stage in the investigation would be to seek further proof of this profiling at the level of content, namely, editorial modification of the substance of individual provisions. 


\subsection{Quantitative Analysis of the Latin Texts of the Weichbild}

Appendix 2 contains a list of variants in the Latin texts. Account has been taken of the modifications which essentially amended the regulations, that is, made them more precise - or, quite the opposite - clouded the originally clear wording of a regulation. For this reason, thousands of linguistic variants and minor editorial amendments are omitted. ${ }^{3}$ It was deliberately decided not to include variants in the list of items that make up the gerada and the principal inheritance (dziedzictwo), because these discrepancies concern relatively marginal details, such as types of fabrics and household vessels. The appendices do not include the final articles appended to the Jewish oath. They come from the Constitution of Courts and contain regulations that can be deemed irrelevant in the Polish context (except the provision concerning the number of jurors). This is confirmed by the fact that some manuscripts omit those provisions.

Statistical calculations have turned out to be a useful tool. They require certain introductory explanations, however. Out data pool is the records of Appendix 2 with all the amendations, defined as divergences from the text of the Gniezno Ms, the earliest extant manuscript. ${ }^{4}$ As each record includes a fairly exhaustive catalogue of variants, some of them tend to be quite large, especially those that take stock of the borrowings from the ortyle, while others are relatively small (in cases where the comparison offers only minor omissions or copyists' errors). Due to peculiarities of the individual texts, the irregularities detected in the course of a statistical review must be treated with great caution. ${ }^{5}$ The results of the comparisons are presented in Figure 2.

3 For a more extensive categorization of the variants, see the Introduction to Annex II.

4 This seems more important than the departure from a presumed Konrad of Sandomierz's archetype (cf. the discussion in Chapter 1 (2.1). The second-oldest text, the Petersburg MS (F 143), was heavily modified.

5 If a given manuscript leaves out one or more articles in a legal text, we have assumed - for the purpose of the statistical calculations - that it does not conform with the Gniezno Ms. The texts of MS Q II 157 (2), the Warsaw Ms, and the Opatów Ms have not been preserved in their entirety. This study has addressed this issue by developing a statistical method to estimate the number of possible divergences from Ms Gn. in the missing passages. It proceeds in three stages: 1) calculation of average number of amendations per page for each text; 2) the determination of the number of missing pages; 3 ) determination of the estimated number of amendations with regard to the text of the Gniezno Ms in the missing passages. In determining the number of pages of the Weichbild missing from the Warsaw Ms and the Opatów Ms (each of them opens with the Weichbild), we have used the Działyńscy Codex IV and the Baworowscy Ms, respectively, because other comparisons show a significant similarity between those pairs. In the Działyńscy Codex IV, the portion of the text which corresponds to the preserved part of the Warsaw Ms makes up approx. 26 per cent of the whole. 


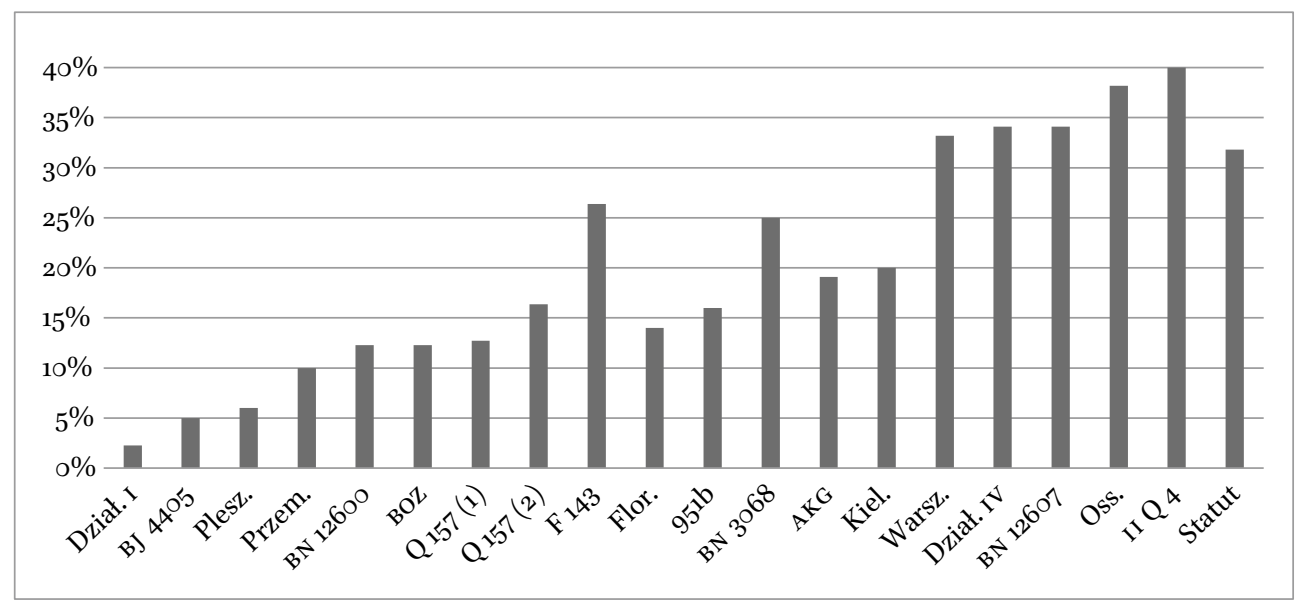

FIGURE 2 Quantitative analysis of divergences from the text of Gniezno Ms in subsequent Latin texts on the basis of data collected in Appendix 2 (in per cent)

The results presented in Figure 2 correspond to the classification of the texts based on their formal features. The highest degree of consistency with the Gniezno Ms can be found in manuscripts of Group I: deviation rates ranging between 2 per cent and 16 per cent, with the exception of the St Petersburg MS (F 143) with a score of 26 per cent (see Table 10 below). The furthest removed from the Gniezno MS are the Żagań manuscript (II Q 4; 40 per cent) as well as other Group II texts, such as the Baworowscy MS (BN 12607; 34 per cent), the Opatów Ms (Oss.; 38 per cent), the Warsaw ms (Warsz.; 33 per cent), and the Działyńscy Codex IV (Dział. IV; 34 per cent). With a score of 25 per cent, Tomasz of Bydgoszcz's MS (BN 3068) stands out from Group I not only because of its amount of ortyle, but also due to the profuse amendations introduced into the text by the copyist. Positioned in the middle ground between Group I and Group II are compilations like the St Florian MS (Flor.; 14 per cent) and the Leipzig MS (951b; 16 per cent), as well as the Częstochowa MS (MS AJG; 19 per cent) and the Kielce Ms (Kiel.; 20 per cent), both of which contain neither the

So, proportionally, the 8.5 pages of the extant text of the Weichbild (for the calculation, the provision ending with the Jewish oath is included) amounts to c. 26 per cent of the text. This means that about 22 pages are lost. In the case of the Opatów MS and MS Q II 157 (2), the estimate takes into account a leaf torn out of the middle of the codex. Ms Pleszew, whose author copied fewer than half of the provisions, presents an altogether different challenge than physical damage to the manuscript. Nevertheless, in this case, a workable estimator has also been devised. I am grateful to Dr Marcin Suder from the AGH University of Science and Technology in Kraków, Department of Applications of Mathematics in Economics for his assistance in finding the appropriate statistical tools. 
case law of the ortyle nor the additional provisions of the Gniezno Ms. Finally, the deviation rate for the Statutes is $3^{2}$ per cent.

\subsection{Group I: MSs Gn., F 143, BN 126oo, Q II 157 (1), Q II 157 (2), Dziat. I, BJ} 4405, Przem., Plesz. and $\mathrm{BOz}$

Direct proof of the indebtedness of Group I manuscripts to the versio Sandomiriensis of the Weichbild is an annotation reproduced in four manuscripts naming Konrad of Sandomierz as the author of the translation. ${ }^{6}$ Mikołaj of Cieszyn, the author of the Gniezno Ms, states that: Iste liber finitus et de Teutunico translatus in Latinum per Conradum scriptorem. An equally unequivocal statement can be found at the beginning of MS Q II 157 (2): Incipit ius municipale per Cunradum civem Sandomiriensem de Theutonico translatum in Latinum. ${ }^{7}$ The divergences between the texts of this group are not profound (see Chapter 2.4.3), with the exception of MS Q II 157 (2) (16 per cent) and the St Petersburg Ms (26 per cent). While the differences between Mss Gn. and Q II 157 (2) were caused by the copyist's omissions, the origins of the divergences in Ms F 143 are illustrated in Table 10, below.

TABLE 10 Petersburg MS (F 143): Quantitative analysis of textual divergences from Gniezno Ms (Gn.)

Number of records

Omission of seven articles

$10^{\mathrm{a}}$

Individual textual divergences

$28^{\mathrm{b}}$

Absence of faults found in Ms Gn. (see Section 4.3)

Textual divergences unique to Group I

$4^{\mathrm{c}}$

Textual divergences unique to Group II

$4^{\mathrm{d}}$

Textual divergences common to Groups I and II $7^{\mathrm{e}}$

$5^{\mathrm{f}}$

a No. 72, 106, 107, 161, 195, 196, 197, 198, 201, and 202.

b No. 1, 7, 8, 9, 14, 20, 21, 23, 26, 32, 34, 36, 53, 57, 63, 65, 66, 86, 116, 117, 122, 125, 126, 127, 148, 149, 15 , and 189 .

c No. 6o, 175, 201, and 216.

d No. $4,181,182$, and 187 .

e No. 3, 22, 28, 45, 91, 151, and 172 .

f No. 49, 53, 93, 102, and 179 .

6 MS Gn., MS Q II 157 (2), MS BN 1260о, and MS вOZ.

7 Identical wording in MS BN 12600. 
Can the high degree of compatibility between the St Petersburg MS and Group II manuscripts be regarded as conclusive proof of a close relationship between the two? In seeking to answer this question, we need to bear in mind that the medieval copyist saw nothing wrong in selecting and adapting his material, including the content of the provisions. The author of the St Petersburg MS left out 12 passages (clauses), some of which match the omissions peculiar to Group I, such as, for example, the provisions that municipal legislation must not contravene God's law, that in no circumstances can an heir be deprived of his portion of the inheritance, and that the sottys (scultetus) should be a free-born local man. ${ }^{8}$ This brings the St Petersburg Ms closer to Group II. Yet, if the size and nature of additions rather than omissions is crucial in demonstrating filiations between texts, making a case for a close relationship between MS F 143 and Group II texts becomes very hard indeed. The additions and modifications that the St Petersburg MS shares with the texts of Group II are on the whole too scanty for a compelling argument. Having said that, there are other ways of addressing the issue:

1) First, only Group II manuscripts and the St Petersburg Ms contain an extensive appendix confirming the plaintiff's right to take precedence in presenting proof in cases concerning the price and quality of food, which corresponds to Article 76 in the German text of MS BJ $169 .{ }^{9}$

2) Second, at the end of Article 1, there is a passage resembling that in Article 3. Crucially, the punishment for a breach the councillors' rulings with regard to measures and weights is set at 36 shillings (szelag), and not 30, as is the case in Article 3. Thirty-six shillings is an amount consistent with the wording of the German texts and with Group II manuscripts, while the fine of 30 shillings occurs only in some Group I manuscripts.

3) Third, exclusively in MSS F 143, AJG, Kiel., Flor., Dział. IV, BN 126o7 and II Q 4, the wording of Article 16 includes the term 'objection', which matches the German text, and not the term 'arrest' (contradicione, arrestacione). ${ }^{10}$ I argue that these conformities with Group II manuscripts are due to the copyist's use of the St Petersburg Ms from one of the Group II manuscripts. Despite the presence of some Group II features, the decision to qualify MS F 143 as a Group I text and treat it as a compilation depends largely on the fact that it features nearly all of the additional provisions characteristic of the Group I text, which must have been the copyist's main source. It is worth noting that some of the divergences in the text of the St Petersburg Ms from the Gniezno Ms also

$8 \quad$ No. 1, 91, and 22.

9 No. 173 .

10 No. 45 . 
occur in Group I manuscripts. ${ }^{11}$ The persistence of this bunch of variants is an important clue which justifies a distinction of two subsets within Group I (see Section 4.3). What is more, the accurate dating of the St Petersburg Ms strongly suggests that the origins of Group II should be sought prior to 1368 .

\subsection{Group II: MSS BN 126o7, Oss., II Q 4, Dziat. IV, and Warsz.}

Close similarities can be found in the following two pairs: Ms Dział. IV / MS Warsz.; and MS BN 12607 / Ms Oss. The text of the Weichbild in the Żagań Ms (II Q 4) is close to that in the latter pair of manuscripts, principally due to its intermix of ortyle, although, admittedly, it has a number of individual features of its own. Let us, at this point, map the filiations that emerge on the basis of comparison of the formal features of the texts:

1) The first pair, which contains the Sandomierz version of the Sachsenspiegel (in its second redaction), matches other Group II manuscripts, with the exception of the provisions that are also missing in the Wawel manuscript MS (BN 168).

2) The Baworowscy Ms (BN 126o7), the Opatów Ms (Oss.), and the Żagan MS are fully compliant, with regard to the arrangement of the articles, with the German texts in the Cracow MS (BJ 169), the Henryków MS (II F 8), the Baworowscy Ms, and the Żagań Ms; it also contains a selection of the ortyle.

All of the texts included in Group II have 24 divergences in common. ${ }^{12}$ In the Działyńscy Codex IV / the Warsaw Ms pair, in addition to those divergences, there is also a group of 12 individual features ${ }^{13}$ as well as 8 divergences from the Gniezno MS which are consistent either with MS BN 12607 or MS II Q 4, one - in the Częstochowa / the Kielce Ms pair. ${ }^{14}$ A common feature of in the Baworowscy Ms, the Opatów Ms, and the Żagań Ms is the presence of another 24 divergences from the Gniezno Ms, apart from the 24 divergences already mentioned. ${ }^{15}$ Furthermore, there is a relatively large group of variants that

11 No. 1, 6o, 93, 175, 179, and 216.

12 No. 1, 3, 10, 22, 45, 52, 60, 79, 84, 88, 91, 93, 102, 106, 146, 166, 169, 170, 173, 175 (without Dział. IV), 195, 197, 206, and 216. The italicized cases also occur in some texts of the Sandomierz version that do not descend directly from Ms Gn. See Section 4.3.

13 No. 5, 37 (also in 951b), 41, 71, 78, 83, 92, 113, 114, 119, 177, and 178. As large portions of the text of Ms Warsz. have not survived, they could not be included in Records $1-165$.

14 Conformity with MS BN 12607 and MS II Q 4 only: Nos. 46, 62, and 220. Conformity with MS BN 12607 only: No. 118. Conformity with MS II Q 4 only: Nos. 122, 150, and 188. Conformity with MS AJG/Kiel.: No. 28 .

15 Nos. 15, 24, 29, 30, 33, 35, 38, 44, 65, 8०, 81, 82, 83, 95, 107, 110, 13o, 142, 158, 163, 165, 193, 204, and 217. Due to damage to the manuscript volume (missing folios), it is not possible to determine the consistency of MS Oss. with Ms Gn. in Records 1-69, 72 and $145^{-152 .}$ 
TABLE 11 Divergences from Gniezno MS (Gn.) in Baworowscy MS (BN 126o7), Opatów MS (Oss.), and Żagań Ms (II Q 4)

\section{Divergences from MS Gn.}

common to MS BN 126o7, MS Oss. and MS II Q 4

$24+24$

found only in MS II Q 4

found only in Ms Oss.

$23^{\mathrm{a}}$

$6^{\mathrm{b}}$

found only in MS BN 12607

found in both MS BN 12607 and MS Oss.

found in MS BN 12607 and MS II Q 4 $4^{\mathrm{c}}$

$13^{\mathrm{d}}$

$4^{\mathrm{e}}$

a No. $2,13,40,48,58,73,75,90,109,112,122,137,141,148,150,156,18$ o, 181, 188, 198, 199, 205, 213 and 214 .

b No. 89, 94, 124, 127, 183 and 196 .

c No. $6,32,118$ and 152 .

d No. 9o, 96, 112, 132, 140, 153, 155, 156, 179, 180, 184, 198 and 199.

e No. 135, 145, 147, 220. The omission in the Opatów MS of a passage Nr. 220 that occurs in the Group II base is probably due to the copyist's individual decision which accidentally resulted in bringing his text in line with a matching passage in texts of Group I.

occur only in some of these three manuscripts. Their distribution is shown in Table 11.

As Table 11 indicates, the Opatów Ms and the Baworowscy Ms have a common source, as they contain a group of variants that are specific to them only and cannot be directly dependent on each other, as both display some individual features of their own. A larger percentage of divergences from the Gniezno MS in the Żagań manuscript than in the Baworowscy MS and the Opatów MS, as well as the presence of sets of individual features in MSS BN 126o7 / Oss. and MS II Q 4 - which undoubtedly have the same source - indicate that they evolved independently of each other. One such individual divergences in the Żagań MS II Q 4 is of special significance, because it draws attention to the wording of Article 24. A closer analysis of this variant has enabled us to date the two groups. The data is shown in Table 12.

In the Gniezno Ms, Article 24 is amplified to include a provision which allows the father to act as proxy for his son in cases of wounding. It contains two parts, one which mirrors a passage in the Magdeburg Bench Law and the Wawel manuscript (Item 2), and the other (Item 1) which comes from another source. All these regulations are present in the Baworowscy Ms, although they are left out in the Żagan ms (Item I). At the same time, the instrument of proxy (Item 2) reappears in Article 87 in the Baworowscy Ms, the Opatów Ms, and the 
Item Article in Ms Issue

Gn. and Nos. in Appendix 2
MS MS BN MS MS II MS BJ MSR,

Gn. 12607 Oss. Q $4 \quad 169$ MS BJ

\begin{tabular}{|c|c|c|c|c|c|c|c|c|}
\hline 1. & {$[24]$ No. $5^{8}$} & $\begin{array}{l}\text { father acting as proxy for his son } \\
\text { in cases of wounding (1) }\end{array}$ & + & + & NA & - & - & - \\
\hline 2. & [24] No. 59 & $\begin{array}{l}\text { father acting as proxy for his son } \\
\text { in cases of wounding }(2)\end{array}$ & + & + & NA & + & - & + \\
\hline 3. & [24] No. 6o & payment of servants' wages & + & + & NA & + & - & - \\
\hline 4. & {$[24]$ No. 61} & complaints about food & + & + & NA & + & + & - \\
\hline 5 . & {$\left[{ }_{76}\right]$ No. 172} & complaints about food & - & + & + & - & - & - \\
\hline 6. & $\begin{array}{l}{[76] \text { No. } 169} \\
\text { and } 170\end{array}$ & $\begin{array}{l}\text { master's liability for his servant's } \\
\text { debts }\end{array}$ & + & - & - & - & - & - \\
\hline 7 . & $\begin{array}{l}{[\text { BJ 169: } 76]} \\
\text { No. } 174\end{array}$ & payment of servants' wages & - & + & + & + & + & + \\
\hline 8. & [87] No. 188 & $\begin{array}{l}\text { father acting as proxy for his son } \\
\text { in cases of wounding }(2)\end{array}$ & - & + & + & + & - & - \\
\hline
\end{tabular}

Żagań Ms (Item 8). The writer's intention was probably to bring together regulations concerning the same issue, since Article 87 deals also with the instrument of proxy.

Konrad of Sandomierz, the author of the Group I archetype, transferred the provision concerning servants' wages to Article 24, whose match is Article 76 in the Cracow manuscript (Item 3). In the Baworowscy Ms, the Opatów Ms, and the Żagań Ms, this provision occurs both in Article 24 (Item 3) and at a point where it matches the order of the German text (Item 7).

In the Baworowscy Ms and the Opatów Ms, the provision for complaints about the price and quality of food from Article 24 is repeated in Article 76 (Item 5); Article 24 mirrors the German base (Item 4). The copyist's intention was probably to replace a longer passage on the master's liability for his servant's debts (Item 6) that had been introduced in the Gniezno Ms following the model of the Sachsenspiegel.

As this analysis demonstrates, the Gniezno Ms is the only text with no duplicated provisions. Comparing the passages in MSS BN 12607, Oss. and II Q 4 shows that they were redacted in different ways. Were we to assume that Group II texts predated those of Group I, we would have to conclude that its author/ translator incorporated the provision concerning servants' payment twice, varying its wording on each occasion. This is too improbable to be acceptable. 
TABLE 13 Provisions concerning servants' wages and complaints about the price and quality of food in Baworowscy Ms (BN 12607)

\begin{tabular}{|c|c|c|}
\hline sue & MS BN $126{ }^{\circ}$ Latin text & MS BN 126o7 Latin text \\
\hline $\begin{array}{l}\text { rvants' } \\
\text { ages }\end{array}$ & $\begin{array}{l}\text { [24] Si autem famulus suam } \\
\text { merdecem super dominum suum } \\
\text { obtinuerit coram iudicio, pro eo } \\
\text { dominus nullam penam iudici } \\
\text { demeretur, sed dominus famulo } \\
\text { eandem mercedem die eodem } \\
\text { solvere tenetur indilate. }\end{array}$ & $\begin{array}{l}\text { [76 numbering acc. to MS BJ } 169 \text { ] Si } \\
\text { servus deservitum parcium super } \\
\text { suum dominum obtinuerit coram } \\
\text { iudicio, pro eo dominus nullam iudici } \\
\text { demeretur penam, et dominus servo } \\
\text { solvere hoc tenetur die eodem. }\end{array}$ \\
\hline $\begin{array}{l}\text { Complaints } \\
\text { about the } \\
\text { price and } \\
\text { quality of } \\
\text { food }\end{array}$ & $\begin{array}{l}{[24] \text { Si alter alterum pro vino }} \\
\text { aut alio potu inculpare voluerit, } \\
\text { evadet, sicud debitum in quo } \\
\text { nullum dominum ostendere } \\
\text { poterit aut protestare. }\end{array}$ & $\begin{array}{l}\text { [76 numbering acc. to MS BJ } 169] \\
\text { Eciam si conqueritur quis de alio } \\
\text { pro cibariis preparatis et coatis, hic } \\
\text { propius est obtinere iuramentis, quam } \\
\text { ille ipsum evadere possit iuramentis. }\end{array}$ \\
\hline
\end{tabular}

Furthermore, the repetition of a passage on complaints about the price and quality of food from Article 24 in Article $76^{16}$ would hardly make any sense. Admittedly, Article 24 refers to the defendant clearing himself of the charge if the plaintiff proves their case, while Article 76 refers to the plaintiff's right to take precedence in presenting proof in such a case, but as a matter of fact, both provisions deal with the same issue.

The comparison indicates that Konrad of Sandomierz's text is earlier than the other texts. The author of the Group II archetype knew Konrad's translation, but he also picked up the German text to make another translation of Article $76 .{ }^{17}$ And after deleting the regulation on the master's liability for his servant's debts, which did not feature in the German Weichbild, he put in its place a newly redacted regulation from Article 24 concerning complaints about the price and quality of food (see Table 13).

This is not the last of the puzzles related to the development of Group II. As we know, MSS BN 12607, Oss., and II Q 4 include supplementary material taken over from ortyle that are also part of the German-language texts of the Baworowscy ms and the Żagań ms. Does this mean that this amplification was already present in the Group II archetype? That is highly unlikely. After all, the authors of MS AJG/Kiel., Ms Dział. IV/Warsz., and Ms Flor. used an

16 Numbering according to Ms Gn. numbering scheme.

17 According to MS BJ 169 numbering scheme. 
unembellished base text. It was supplemented with the ortyle only later, as evidenced by the text of the Weichbild in MS BN 12607/Oss., MS II Q 4, and, on the authority of Emil Kałużniacki, the Sanok manuscript (see Section 3.20). And, if that line of thought were to be pursued, those additions would have had to be later deleted in MS AJG/Kiel., Ms Dział. IV/Warsz., and Ms Flor., a totally implausible conclusion.

What this comparative analysis shows is that the archetype of Group II was created after Konrad of Sandomierz, the author of Group I, completed his translation, and not later than 1368 (see Section 2.2). Originally, the text contained no ortyle. As to the questions asked in Chapter 1 - whether the supplementary material was introduced first in the German text or simultaneously in the German and Latin texts - there is no conclusive answer. It seems that the former alternative is more plausible. This would mean that the augmented German text was subsequently juxtaposed with the Latin text, a collation which produced a series of bilingual manuscripts. However, the fact that some manuscripts (the Opatów MS and the lost Sanok manuscript) carry only the Latin Weichbild may indicate that the demand for the bilingual text was not that great. The copyists would then supplement their received text with the ortyle from the Group II text, which reproduced the article sequence of the German-language manuscripts.

\subsection{Group III (Hybrid Compilations): MSs AJG, Kiel., Flor., 951b, and BN 3068}

The relations between similar texts of Group I and Group II in the Częstochowa Ms (AJG) and the Kielce Ms (Kiel.) are not too difficult to make out. ${ }^{18}$ Their base text is a Group II manuscript which has 19 divergences from the Gniezno MS that are common to the AJG /Kiel. pair (see above), ${ }^{19}$ as well as a number of other variants in common with the Baworowscy Ms, the Opatów Ms, and the Żagań Ms. ${ }^{20}$ Among them is a twice-copied provision concerning servants' wages, a reduplication which appears to mirror the arrangement of the text in Group II manuscripts. However, assigning the AJG/Kiel. MSs pair to a separate group of 'hybrid' manuscripts (Group III) is done not without good reason. Not only do both texts contain in Article 76 additions characteristic of Group I, taken over

18 Divergences from MS Gn. common to both texts - No. 14, 26, 53, 59, 131, 154, 171, 192 and 204; peculiar to MS Kiel. only - No. 50, 55 and 61 .

19 No. 1, 3, 10, 22, 45, 52, 60, 79, 84, 88, 91, 93, 102, 106, 166, 175, 197, 206 and 216.

20 No. 110 and 175. Single case of conformity of the AJG / Kiel. with the Oss. consists in an omission and is probably accidental (No. 183). In four cases conformity was only found with the II Q 4 (nos. 58, 90, 122 and 141), in one with the BN 12607 (No. 89), in three with BN 12607 and II Q 4 (nos. 135, 151, 220), and in two with the BN 12607 and Oss. (nos. 156, 172). 
from the Sachsenspiegel, but they also include Article 55 of the Gniezno Ms, which is omitted in Group II texts. It seems that the copyist skipped Article 54 so as to synchronize his text with the numbering scheme of the Group I base text. The AJG/Kiel. Mss were thus created as a result of the copyist collating texts from both groups. Yet his redaction was by no means mechanical. His text displays a significant number of individual features - chiefly omissions - such as, for example, the omission in Article 24 of the requirement that a father must first be cleared of the charges against him before he can act as proxy for his son charged with the same offence. ${ }^{21}$

In the St Florian MS, in 110 records in Appendix 2 which cover Articles 50-109 there occur merely three divergences from the Gniezno Ms, whereas in the other part, there are as many as 29. This goes to show that the Weichbild in the St Florian MS is a product of a virtually mechanical combination of two parts that descend from different groups of manuscripts and that the assignment of the St Florian MS to Group III (compilations) can be justified not only on the basis of its formal features, like the copying of the article on the gerada (Article 61 in MS Gn.) in two places corresponding to the location of this text in Group I and Group II. What can also be noted at this point is that the dissonance caused by the reduplication of this article prompted the copyist to skip Article 55 of the Gniezno Ms. One more notable peculiarity of the St Florian MS is that its duplicate provisions on the gerada are not identical. This discrepancy offers further strong proof of the claim that the copyist used two texts, one of which was close to the Żagań Ms, but not augmented with ortyle.

In the case of the Leipzig manuscript (MS 951b), the compilation process was the reverse of that of the St Florian Ms. In Articles 1-62 in Appendix 2, only a few divergences from the Gniezno ms have been found, including those shared with the Marcin Zabowski's Ms. ${ }^{22}$ As both contain a number of individual features, any direct connection between these two texts must be ruled out. ${ }^{23}$ At the same time, the presence of identical variants in both cannot be attributed to anything but a shared base. In the margins of the first folios of the Leipzig manuscript, there are glosses peculiar to the texts of Group II, but they are discontinued at Article 63. At that point, the copyist evidently decided that he would rather interweave the annotations with the main text. All of the 23 divergences from the text of the Gniezno MS Gn. in the Leipzig MS are identical with those in the Weichbild of the Żagan manuscript. However, the base used by the copyist of the Leipzig manuscript could not have been a

\footnotetext{
$21 \quad$ No. 59.

22 No. 65, 89, 90, 101, 104, 111, 112.

23 No. 74; No. 4, 98, 128 and 131.
} 
close copy of the Żagań Ms, as his text is at times closer to the Statutes than the Żagan MS. ${ }^{24}$ Unfortunately, a conclusive identification of the source used by the author of the Leipzig MS seems impossible.

There are more than a few textual divergences from the Gniezno Ms in the Tomasz of Bydgosz MS (BN 3068). The author of the latter, Tomasz of Bydgoszcz, evidently tried to make his text easy to use and annotate by prospective commentators. He divided the articles into smaller units and provided them with rubrics in red. He was, however, not consistent in that effort, and after several dozen articles, he abandoned his original purpose. In addition, he also introduced, in the margins, brief notes in black ink on the content of the adjacent passages. The Tomasz of Bydgosz MS is characterized by numerous divergences from the Gniezno Ms. In several cases, these are individual divergences. ${ }^{25}$ But not less numerous are variants consistent with characteristic features of the texts in Group II. That similarity, however, does not make MS BN 3068 just another Group II text, as on numerous occasions it follows the Gniezno manuscript, while Group II texts do not. ${ }^{26}$ A notable discordance can be found, for example, in the article on escheat, which in fact has a completely different version in each group. In the Tomasz of Bydgosz Ms, both versions of the provision are included in full. ${ }^{27}$ The manuscript is dated to the early 16 th century, but the terminus a quo should be moved to a time after 1506, as the text is clearly influenced by Jan Łaski's Statutes. ${ }^{28}$ So, no doubt under the influence of the Statutes, the provision of Article 69 concerning the purchase of a stolen horse appears next to Article 38 , which deals with this issue, but it then reappears as Article 69 - exactly as it does in the manuscripts of Group I and Group II. There are, however, several articles in MS BN 3068 whose wording is analogous to that in Group II manuscripts and not to the Statutes. ${ }^{29}$ The copyist,

24 No. 193, 200, 213 and 217. Another instance of textual conformity can be found in No. 112 where a series of omissions is common to MS BOZ, MS $951 \mathrm{~b}$ and the Statutes.

25 No. 11, 18, 19, 25, 39, 41, 76, 85, 87, 115, 123, 138, 143, 156, 176, 187, 191, 212 and 215. It is worth adding that occasionally a change of one word could alter the whole regulation. Article 6 provides for the option of appointing a deputy sottys so that justice could be done to any thief caught in the act even if the sottys was absent. In MS BN 3068 the word 'burghers' is replaced by 'councillors', with an additional remark on the margin, Quis debet elegi in scultetum.

26 No. 2, 35, 44, 45, 46, 58, 80, 81, 82, 83, 84, 90, 102, 147, 198 and 205. Unfortunately, the available data afford no clue which of the Group I texts was used by Tomasz of Bydgoszcz, the copyist of BN 3068 .

27 No. 156.

28 See No. 12, 16 and 24; No. 64 was probably also taken from the Statutes.

29 No. 29 and 30. 


\begin{tabular}{|c|c|c|c|c|c|c|c|}
\hline & $\begin{array}{l}\text { Baworowscy } \\
\text { MS (BN 126o7) } \\
\text { German }\end{array}$ & $\begin{array}{l}\text { MS BN } \\
\text { 126o7 } \\
\text { Latin }\end{array}$ & $\begin{array}{l}\text { Żagań MS } \\
\text { (II Q 4) } \\
\text { German }\end{array}$ & $\begin{array}{l}\text { MS II Q } 4 \\
\text { Latin }\end{array}$ & $\begin{array}{l}\text { Opatów } \\
\text { Ms (Oss.) }\end{array}$ & $\begin{array}{l}\text { Easki's } \\
\text { Statutes }\end{array}$ & $\begin{array}{l}\text { Tomasz of } \\
\text { Bydgoszcz's } \\
\text { MS (BN 3o68) }\end{array}$ \\
\hline Ortyl 1 & $\begin{array}{l}\text { reference to } \\
\text { Article } 74\end{array}$ & Article 48 & Article 48 & Article 48 & Article 48 & Article 48 & Article 15 \\
\hline Ortyl 2 & Article 74 & Article 73 & Article 73 & Article 73 & Article 73 & Article 73 & $\begin{array}{l}\text { Article } 48 \\
\text { and } 73\end{array}$ \\
\hline
\end{tabular}

it seems, must have had at his disposal a text close to the Baworowscy Ms. ${ }^{30}$ After all, he refers to the German text in that bilingual manuscript when, in the final part of the addendum to Article 13, he introduces his own, improved translation consistent with the German text. ${ }^{31}$ The use of a manuscript close to the Baworowscy MS is further evidenced by his handling of two ortyle. ${ }^{32}$ The placement of the two ortyle in various manuscripts is presented in Table 14.

As noted in Chapter 1, Article 48 in the Baworowscy Ms contains no German ortyl, but instead, refers the reader to Article 74. The reference is misleading because there are two separate regulations of the matter at hand, as seen by the wording of the Latin text in the same manuscript, the Latin texts of the Żagań Ms and the Statutes, and in the German text of the Żagan ms. Why the author of the Baworowscy Ms put in a reference to Article 74 in the German text of the Weichbild remains a mystery. In fact, he has a regulation that is very similar in two places, in Article 48 and 73, which gives the impression of making good on the reference in the German text. Moreover, in the German text in the Baworowscy Ms and in the Latin text in Tomasz of Bydgoszcz's Ms, the second ortyl is incorporated into Article 74 and not Article $73 \cdot{ }^{33}$ On the whole, the text in Tomasz of Bydgoszcz's ms is in some parts closer to the German text in the Baworowscy Ms than to other manuscripts with ortyle. It is also worth noting that the copying twice of the regulation from Ortyl 2 resulted in Ortyl 1 being transposed form Article 48 (its proper place) to below Article 15 . Further notable proof of direct filiation between MS BN 3068 and MS BN 12607

30 No. 6, 19 and 96. Individual alterations were made in MS BN 3068 in the numerous additions from Group II; see No. 142, 158, 165 and 172.

$31 \quad$ No. 38.

$32 \quad$ No. 163.

33 Numbering according to Ms Gn. numbering scheme. 
is afforded by a short passage with the explanation that a talent is equal to 20 shillings. It appears first as a gloss to Article 5 in the Baworowscy MS and is then incorporated into the main text of MS BN 3068 by Tomasz of Bydgoszcz. ${ }^{34}$ In all, his edition of the Weichbild is carefully prepared and includes a number of useful supplements, like lists of regulae iuris and glossaries of Latin terms, one of which comes from the Działyńscy Codex I (see Section 4).

\subsection{Summary: The Division of the Latin Weichbild Texts on the Basis of Content}

The division of the Latin Weichbild texts into distinct groups is further corroborated by another series of comparative analyses of the content of texts collected in Appendix 2. The substance and shape of the provisions fall into patterns that correspond to the division into three groups distinguished in the previous subchapter 1. Moreover, a close textual study has revealed enough clues for ad quem dating of the two main groups of texts: Group I not later than 1359, with the Gniezno manuscript as a reference point; and Group II not later than 1368, with reference to the Petersburg Ms. The latter does not quite fit the profile of Group II, but it is indebted to an earlier manuscript text which certainly represented that group.

Statistical analyses show that the texts of Group I conform to a large extent to the text of the Gniezno ms, the earliest manuscript in that group, while the texts of Group II are far more differentiated. The complex network of modifications in the texts of Group II are, after all, a record of the evolution of the Weichbild. On this basis, the history of the Weichbild can be reconstructed in the following stages: 1) the creation of the archetype of Group I; 2) the creation of the archetype of Group II (manuscripts whose content arrangement resembles the arrangement of the German-language Silesian-Małopolska compilation); 3) the augmentation of the German text with ortyle written in German; 4) the creation of bilingual Latin-German manuscripts with the German ortyle and their Latin translations; and 5) replacement of the bilingual texts with Latin-only texts augmented with ortyle.

The interaction of the texts among one another produced cross-breed compilations. In this scheme, such texts constitute the 'hybrid' Group III. The compilers' techniques varied a great deal. Some tried to combine the features of both main groups intelligently, ${ }^{35}$ but others merely cobbled together bits and pieces of text from Group I and Group II. ${ }^{36}$ An odd man out is the text in Tomasz of Bydgoszcz's ms, which is clearly dependent on the authorized

\footnotetext{
$34 \quad$ No. 19.

35 As in Ms AJG/Kiel.

36 E.g. the St Florian Ms, the Leipzig Ms.
} 
version of Łaski's Statutes, which means that it must have been compiled after the arrival of print. of the Weichbild

After establishing that the texts of the Latin Weichbild belong to or descend from two main groups, the question that can be asked is what led to the emergence of those groups of texts. To answer this, I have decided to compare the Latin texts with their German counterparts. The aim of this investigation is to assess the accuracy of the translation and to establish whether the differences between the two groups of Latin texts may have been the result of following different German base texts.

\subsection{Selection of Texts and Method of Comparison}

The copyists' decisions, which reflected either their own judgement or the influence of their masters, could not help but leave a mark on the final wording of the legal documents they copied or edited. Naturally, some of the divergences between texts result from error or negligence and were wholly unintentional. The combined operation of all the factors, both intentional and unintentional, produced multiple versions of a notionally single text, like the Weichbild. One well established method of ascertaining the ordering of such an assemblage of texts is to trace their lines of descent. In the case of the Weichbild, it has been possible to distinguish two groups of affiliated texts, a third group consisting of compilations of the two, and the Commune incliti, a definitive printed synthesis which was released with a seal of official authorization. The German-language texts are generally perceived as remote ancestors of the Latin Weichbild of the late Middle Ages. While acceptable as a broad generalization, this proposition is in need of a great deal of nuance and heightened scrutiny, not least with the tools of quantitative analysis. To that end, I have gathered in Appendix 3 a comprehensive collection of data that could be used to verify the degree of consistency of the German Weichbild of selected Latin texts representing Group I (descended from the Gniezno MS, dated 1359) and Group II, with the Baworowscy Ms. This Baworowscy Ms was selected as its base text because it contains the largest number of formal similarities with the German-language Silesian-Małopolska compilation of the Weichbild. ${ }^{37}$ The

37 Of the Group II manuscripts, the Opatów ms has not survived in its entirety, while the Żagań Ms counts as more distant from the Gniezno ms because of the greater number of its individual divergences. Furthermore, in the Żagań ms, Article 8 of the Latin Weichbild 
third Latin text selected for this in-depth comparison is the Weichbild from the Działyńscy Codex IV. The latter has occupied a special position in the family of Latin texts of German and Magdeburg Law after Zygfryd Rymaszewski established that the Sachsenspiegel in the Działyńscy Codex IV is a second redaction of the versio Sandomiriensis. That fact - as well as the unique formal similarities of MS Dział. IV with the German-language Wawel Ms - raises the question about the profile of the Weichbild in that codex. Here, my objective is to check whether there are any indications that would justify the repositioning of the Weichbild in the Działyńscy Codex IV in relation to its twin in the Warsaw Ms. My reference for the divergence study is the earliest relevant German text of the Weichbild from the Cracow Ms. Each of the divergences from the latter that are found in the Latin translation is set in a broader context. The aim is to trace its source and to make comparisons with other texts of the German Weichbild (except for the strongly modified and abridged text in the Żagań Ms), Magdeburg Legal Instructions for Wroctaw, and the Magdeburg Bench Law.

Thousands of samples - the product of comparative analyses of the Latin texts of the Gniezno ms, the Baworowscy ms, and the Działyńscy Codex IV with their German predecessors - are arranged in more than 200 records which showcase the divergences in the translation of specific provisions or clauses. Systematically trawling through those texts has revealed the presence of two types of divergences from the Cracow Ms. The first such divergence is represented by a set of features that show a remarkable persistence in the process of manuscript transmission. The second such divergence consists of those aberrations from the Cracow Ms that are peculiar to individual texts. Each of them - the persistent and the unique - will be discussed separately.

\subsection{Divergences from the German Base Texts That Are Common to All Latin Texts}

In 72 records $^{38}$ of Appendix 3 (approx. 34 per cent of all records; approx. 36 per cent, if the records registering material from the ortyle in the Baworowscy Ms are excluded), ${ }^{39}$ the register of divergences from the Cracow manuscript includes all Latin texts selected for analysis. This means that these variants must have been introduced at the beginning, by Konrad of Sandomierz, the

was omitted by mistake. In this phase of our analysis, we are not concerned with additions to the Baworowscy Ms from the ortyle; they were discussed in Chapter 1.

38 No. 307, 308, 310, 313, 314, 315, 321, 323, 329, 330, 333, 334, 335, 336, 337, 339, 340, 344, 345, $346,347,348,349,351,353,354,355,357,358,359,361,366,369,370,372,373,375,378,381$, $382,384,385,388,390,393,396,399,401,403,405,409,410,412,415,417,420,421,423,426$, $431,438,441,444,454,466,487,488,491,504,5 \circ 5,508$, and $5 \circ 9$.

See nos. $317,319,325,328,389,422,439,446,447,476,482,485$, and 502 . 
founding figure of Group I. ${ }^{40}$ In most cases, they are amendments or additions which serve to make the text easier to understand. Demonstrative or personal pronouns were replaced with more specific nouns or phrases - for example, 'he' became 'scultetus' (the village headman) and 'he' became 'he that wounded another man'. ${ }^{41}$ Moreover, in the Latin text, the translator takes care to use ipse for 'plaintiff' and ille for 'defendant' with rigorous consistency. $\mathrm{He}$ also ensures that he provides explanations whenever necessary. He certainly deserves a compliment for a job well done. Apart from being more direct in naming the law's cast of characters, the original translation does not skimp on other additions to clarify the abstruseness of a legal phrase or to draw the line when a provision leaves too much up for debate, ${ }^{42}$ for instance, by making sure that verbal abuse qualifies as insult of a member of the jury. ${ }^{43}$ In general, this approach leads to the amplification of the original text; elisions are very rare and affect words that perhaps should not have been omitted. ${ }^{44}$

Occasionally, when a word in the German text did not fit Polish realities, it was substituted in the earliest translation by a more appropriate term for example, keiseris straze or 'Emperor's highway' became strata regia 'royal highway'; ${ }^{45}$ pfenningen became pecunia 'money', ${ }^{46}$ However, some substitutions impinged on the (legal) substance, as when 'debt cases' became 'court cases', which extended the scope of the regulation, ${ }^{47}$ even though at another point in the text (provision on guarantee), Konrad of Sandomierz rendered the term 'property' as 'money'48 and restricted the general provision on suing a person about to set off on a long journey to action of debt. ${ }^{49}$ Another arguable substitution was the introduction of the terms agnatus or cognatus in place of a personal pronoun. ${ }^{50}$ Article 41 became a regulation devoted not only

40 Admittedly, in some cases, changes can be noticed in the Latin texts but they were made already on the modification that is present in the original translation. No. 438 (addition in the BN $126 \circ 7$ and Dział. IV), no. 378 (omission of a passage in the BN 126o7), nos. 330, 335 , and 387 (amendments in the Gn.).

41 Cf. No. 308, 310, 315, 321, 323, 373, and 417 .

42 No. 330, 333, 334, 336, 337, 346, 366, 369, 370, 372, 375, 377, 381, 382, 384, 385, 393, 403, 410, $412,415,421,423,441,444,504$, and 505 . For abridgements not affecting the sense of a regulation, see No. 344 and 493 .

$43 \quad$ No. 336.

$44 \quad$ No. 466.

45 No. 353. Cf. also No. 399.

$46 \quad$ No. 307.

$47 \quad$ No. 357.

$48 \quad$ No. 441.

$49 \quad$ No. 335.

50 No. 359. Departures from the German text should be looked at in their context, i.e. the whole provision and its meaning. On some occasions the omission of a word or phrase need not result in a significant change of the legal meaning, e.g. a one-off use of the term 
to hereditary rented property, but generally to any property received in any manner from a monastery or its owner. ${ }^{51}$ In its references to compurgation, the Weichbild as a rule set down the conditions that had to be met by those participating in this procedure. When Konrad of Sandomierz came across an article in the German text that mentioned no such requirements, he supplied them himself. ${ }^{52}$ In Articles 51-56, which set down the conditions and procedures for action of assault and wounding, he added some annotations of his own, for example, a reminder of the advantage gained by the party that is allowed to present their case first in the order of preceding (i.e. proof in the form of the judicial oath). ${ }^{53}$ A clause that is introduced in the Latin texts of both groups specified what books could be made part of the gerada - while the German text spoke of religious books in general, the translator's addition in fact excluded them, with the exception of those that were used by women for prayer and worship. ${ }^{54}$ By modifying the wording of the Jewish oath, the translator made it look like the formula of the purgatory oath..$^{55}$ However, in other cases, it is difficult to conjecture or to find clues as to why an alteration was introduced. ${ }^{56}$

In 17 instances out of the 72 mentioned above, the divergences from the Cracow manuscript have parallels in other German texts, namely, in 12 cases in the Wawel manuscript and elsewhere ${ }^{57}$ and in four cases exclusively in the Wawel Ms. ${ }^{58}$ Divergences in numerous records ${ }^{59}$ can be matched with provisions of the Magdeburg Bench Law in the wording known from the MS II Q 3 from the Wrocław University Library, printed by Paul Laband. Four out that number do not conform with the text known from the Wawel manuscript. ${ }^{60}$ In one case, the divergence is matched exclusively in the German-language Henryków MS (II F 8), but it is a minor editorial elision, which is not that significant. ${ }^{61}$ What all these examples show is that Konrad of Sandomierz, the author of the earliest Latin translation of the Weichbild, made use not only of a German text which was very close to the Cracow manuscript, but also of other

bona 'property' in the Latin text in place of cins gut, or 'rented property' in the German Weichbild (No. 372).

$51 \quad$ No. 375 .

52 No. 39o.

53 No. 396.

54 No. 426.

$55 \quad$ No. 508.

$56 \quad$ No. 488.

57 No. $314,329,347,348,354,355,358,361,388,454,487$, and 509 .

$58 \quad$ No. $314,329,487$, and 509 .

59 No. 313 (MSR only for Gn.), 340, 345, 347, 348, 349, 354, 355, 358, and 361 .

6 o No. 313 (MSR only for Gn.), 340, 345, and 349.

$61 \quad$ No. 351. 
manuscripts that happened to be closer to certain other original sources of the Weichbild.

Whereas the divergences from the Cracow manuscript that we have discussed thus far usually did not impinge on the normative content of the original text - as their main purpose was to assist the reader's comprehension - about one-half of another raft of 17 divergences have a great practical importance. ${ }^{62}$ The translator follows the Wawel MS in revising the provision of Article 24, which addresses the situation when father and son are charged with the same crime. He introduces the additional requirement that the father cannot act as proxy for his son unless he has cleared himself of the charge. ${ }^{63}$ Another modification concerns the rules of succession in the case of inheriting from a grandfather by a grandson who was born to his daughter. The Latin text makes the grandson's claim dependent on his mother's having a share in the decedent's estate. This clause, which is absent from the Cracow manuscript, can be found in the Wawel and Henryków manuscripts. ${ }^{64}$

One of the claims made in this study (see Chapter 1 ) is that the Cracow manuscript is not the archetype of the German version of the Silesian-Małopolska compilation, which, regrettably, has not survived. The comparative analyses of variance in the extant German texts and the primary sources of the Weichbild give strength to the conjecture that such a base manuscript did exist and was a parent text of the Wawel Ms. The differences between the two amounted to no more than a handful of unintentional omissions, probably caused by the copyist's skipping one of a pair of neighbouring phrases that began with the same word. This is suggested by the significant numerous instances of the Latin text's conformity with the Wawel MS in places which correspond to omissions in the Cracow Ms. ${ }^{65}$ However, at the same time, the provisions of the Wawel Ms that contain words and phrases omitted in the Cracow Ms have some individual features that not are absent from Konrad of Sandomierz's translation. It is the last of these findings which offers proof of the claim that Konrad of Sandomierz used a text that was not identical to the Wawel Ms.

62 In two instances, the Latin text is closer to the Wawel Ms than to the Cracow Ms; neither divergence affects the legal regulation (No. 314 and 329). In most cases, the additional explanation or concretization did not modify or interfere with the regulation itself (No. $345,347,355,358,454$ or 5 o9). The elision or omission of a word or phrase would usually have a negative effect on the clarity of the text, but here, too, the content of the regulation was not affected (No. 491).

63 No. 340.

64 No. 388. For more additions, see No. 354 and 361.

65 That is probably the case in No. 348,355 , and 388 . 
Finally, barring a few exceptions, all the divergences that have no match in the Cracow ms are amplifications. They supplement the bare translation with practical explanations; some are substitutes of German terms whose function is to adapt the text to Polish realities. A close study of all types of divergences has produced new insights into the range of Konrad of Sandomierz's sources and techniques.

\subsection{Individual Divergences from the German Base in the Latin Texts}

Apart from divergences that are 'shared', that is, replicated in more than one manuscript, there are divergences which mark the individual character of each text, or, from the point of view of our comparative analysis, which reflect a lack of conformity between them. The number of individual divergences between the Gniezno and the Cracow manuscripts is $5^{1}$ (45), which serves to express the distance between the two texts; $; 6$ for MS BN 12607 , it is also 51 ; ${ }^{67}$ and for MS Dział. IV, it is $34 .^{68}$ The lower number of divergences in the Działyńscy Codex IV is primarily the result of its shorter length due to the omission of the several articles. These metrics offer some ground for a conjectural reconstruction of the archetype of Group II. We may presume that it was more consistent with its German base than the Latin text in the Baworowscy Ms, as some of its divergences from the German texts do not occur in other manuscripts within this group. ${ }^{69}$

As in the case of the shared divergences, some of the individual differences can be accounted for by reference to a German text which is different from the Cracow ms. The metrics on which this argument rests are presented in Table 15. This comparative analysis does allow for matches indicating a level of conformity with more than one German text other than the Cracow Ms. The number of such matches, or parallels, with one of the other German texts is shown in square brackets (the numbers of those records are highlighted in footnotes 1-12).

66 No. 302, 304, 309, 318, 327, 330, 335, 341, 343, 365, 368, 371, 374, 383, 385, 387, 394, 395, 406, 411, 437, 440, 442, 443, 448, 449, 451, 452, 453, 456, 458, 459, 462, 474, 477, 478, 479, 481, $483,486,490,492,493,494,495,496,497,499,500,501$, and 503 . While the samples in No. $341,385,387,459,492$, and 503 show that MS Gn. has a place of its own in the family of the German-language texts of the Weichbild, its first Latin translation by Konrad of Sandomierz is probably a direct descendant of the German base. Cf. the discussion in Section 4.3.

67 No. 303, 306, 311, 312, 316, 343, 362, 367, 378, 379, 380, 383, 391, 392, 406, 408, 409, 413, 414, $416,419,425,429,433,434,435,438,440,442,443,445,45^{\circ}, 45^{2}, 456,45^{8}, 462,465,468,47$, $477,480,483,484,486,489,490,493,495,496,498$, and $5 \circ 7$.

68 No. 301, 305, 318, 324, 326, 338, 343, 35०, 356, 363, 364, 367, 376, 388, 397, 398, 407, 425, 429, 43 o, 432, 438, 445, 450, 457, 462, 467, 471, 473, 475, 479, 498, 499, and 507.

69 E.g. No. 436. 
TABLE 15 Conformity of the Latin texts in MS Gn., MS BN 12607, and MS Dział. IV with the German texts in the MSR, MS BJ 168, MS BN 12607 and MS BJ 170a as indicated by divergences that do not conform with MS BJ 169

MS Gn. MS BN 126o7 Lat. MS Dział. IV

$\begin{array}{llll}\text { Conformity with the MSR } & 5(1)^{\mathrm{a}} & 3(1)^{\mathrm{b}} & 4(1)^{\mathrm{c}} \\ \text { Conformity with MS BJ 168 } & 4(1)^{\mathrm{d}} & 4(1)^{\mathrm{e}} & 7(6)^{\mathrm{f}} \\ \text { Conformity with MS BN 126o7 Ger. } & 4(3)^{\mathrm{g}} & 5(4)^{\mathrm{h}} & 1(1)^{\mathrm{i}} \\ \text { Conformity with MS BJ 170a } & 6(1)^{\mathrm{j}} & 3(\mathrm{o})^{\mathrm{k}} & 3(0)^{\mathrm{l}}\end{array}$

In the table notes records with evidence of parallels (conformity) between the Latin text and only one of the German texts in MSR, MS BJ 168, MS BN 12607 Ger., MS BJ 170a are highlighted.

a No. $313,332,342,363$ and 364 .

b No. $332,35^{2}$ and 360 .

c No. 332,363 and 364 .

d No. 322, 342, 455 and 510 .

e No. $35^{2}, 360,365$ and 455 .

f No. $322,352,436,461,464,472$ and 506 .

g No. 404, 408, 418 and 510 .

h No. 322, 400, 408, 418 and 436 .

i No. 404 .

j No. $313,331,342,363,364$ and 455 .

k No. 352, 36o and 455 .

l No. 352,363 and 364 .

The most important indicator in our search for the conjectural Germanlanguage base text is the list of matches with only one German text other than the Cracow Ms. The findings can be summarized as follows:

1) The Gniezno Ms displays exclusive conformity with the Magdeburg Bench Law in 1 case, with the Wawel MS (BJ 168) in 1 case, with the Baworowscy MS (BN 12607) in 3 cases, and with MS BJ 170a in 1 case, which is probably of no significance as it concerns a contingent omission.

2) The Latin text in the Baworowscy Ms exhibits exclusive conformity with the Magdeburg Bench Law (1 case), the Wawel ms (1 case), and with the German text in the Baworowscy Ms (4 cases, excluding additions from the ortyle which are placed in parallel to the German and the Latin text).

3) The Działyńscy Codex IV displays exclusive conformity with the Wawel MS (6 cases) and in 1 configuration with the Magdeburg Bench Law and the Baworowscy Ms, which is a case that is also evidenced in the Gniezno MS.

These results lead us to the conclusion that Konrad of Sandomierz, the author of the conjectural Group II archetype, and the author of the text in the Działyńscy 
Codex IV relied on more than one German text for their additions and amendments. The results also demonstrate the extraordinary usefulness of the quantitative approach, as it can bring into sharp relief the differences between groups of manuscripts. In effect, quantitative analysis opens up a new perspective on textual variance (i.e. the formal features discussed in Section 1 and the substantive differences analysed in Section 2), as well as the scope and the role of the German-language texts in the process of manuscript transmission.

\subsection{Summary: Reliance on Different German Base Texts as a Factor in the Differentiation of the Latin Texts of the Weichbild}

The analysis of the data collected in Appendix 3 leads to the following conclusions: first, the divergences from the German base texts that are common to all Latin texts are, for the most part, additions which seek to specify or explain the original wording or construction. While some of these additions do not match the German text of the earliest Cracow manuscript (MS BJ 169), they seem to lock in with another German text, that of the Wawel manuscript (BJ 168). The introduction of amplifications of this kind no doubt signals the translator's concern for the clarity of the legal text, which, as we have noted earlier, was an individual trait of Konrad of Sandomierz, whose authorship of the texts of Group I can be treated as a certainty.

Second, while some characteristic divergences occur only in the texts of Group I, other divergences which exhibit a great deal of minor deviations are typical of Group II. In the case of divergences that appear only once, it is possible that they, too, have their origins in a lost German source.

The analysis shows that the emergence of two different groups of texts of the Latin Weichbild results from their authors' use of different (i.e. not identical) German base texts. We may now, having all these findings at hand, revisit the problem of the Latin Weichbild and ask whether there was just one Latin translation or whether there were two different translations.

\section{4 Group I: Versio Sandomiriensis}

\subsection{Complex Basis of the Original Latin Translation}

The foregoing comparative analysis of the Latin Weichbild in the Gniezno Ms and the German text of the Cracow manuscript has brought to light a large number of divergences which are of no great importance for the filiations in the inner circle of the foundation manuscripts. Some of these changes are modifications that do not affect the meaning of the regulations which they augment for the purpose of clarification or contract by eliding a word or a 
phrase. ${ }^{70}$ However, the majority of the divergences introduce substantive modifications, which, in a number of cases, have parallels in German texts other than the Cracow M s. ${ }^{71}$ In addition to his base text, Konrad of Sandomierz studded his translation with words and phrases that have their matches in the German texts of the Magdeburg Bench Law, the Wawel MS, MS BJ 170a, and the Baworowscy Ms (Table 15 in Section 3.3), and also from the Magdeburg Legal Instructions for Wroctaw of $1261 .{ }^{72}$

Two of these German texts can be rejected: 1 ) it has been already mentioned that the convergence of the Gniezno MS and BJ 170a was probably accidental; and 2) if we focus our attention on parallel omissions, none is as significant as the absence of Articles 30 and 50 of the Magdeburg Bench Law from both the Sandomierz version and the German-language texts of the Weichbild. It is a clear indication that Konrad of Sandomierz had either no direct access to the Magdeburg Bench Law, or chose to not use it.

In my opinion, he may well have had at his disposal, in addition to his base text, close to the Cracow Ms (which had features of German-language text in the Baworowscy Ms), the Magdeburg Legal Instructions for Wroctaw of 1261 and another German text (later lost) which combined some features of the Magdeburg Bench Law and the Wawel manuscript. The Wawel manuscript itself would be a descendant of that conjectured missing-link manuscript.

\subsection{Characteristic Features of the Sandomierz Version}

Konrad of Sandomierz was not only a translator, but also the author of another version of the text, probably longer than the one in the Cracow manuscript, aloof from all of the extant German texts. If the characteristic features of the Weichbild are put side-by-side with those features of the Gniezno Ms that are important in connection with the Cracow manuscript, we can note the following:

1) additional provisions that come from the Sachsenspiegel (Articles 57, 76, and 77 of Ms Gn.) and from the Magdeburg Legal Instructions for Wroclaw of 1261 (Article 55$) ;^{73}$

70 No. 340, 383, 394, 395, 409, 411, 445, 452, 455, 456, 462, 474, 477, 479, 483, 486, 493, 494, 496, and 500 .

71 One such exception is the clarification that the court in question is the Magdeburg Bench, whose president is called the Burggraf of Magdeburg; in MS BJ 169, this explanation is omitted (No. 455).

72 Article 72 of the Magdeburg Legal Instructions for Wroctaw of 1261 was the parent text of Article 55 in the Gniezno Ms, as we have shown in Section 1.

See Table 2.5. 
2) changes in the order (sequence) of the provisions; some changes - like gathering the provisions on the gerada, hergewet, and general inheritance next to each other - seem to be dictated by simple common sense; ${ }^{74}$

3) some substantive features in the form of the absence of a passage that is present in the Cracow Ms ${ }^{75}$ - only a few such omissions occur in the German texts of the Weichbild, other than the Cracow Ms; ${ }^{76}$

4) some substantive features in the form of additions of words and phrases that are absent in the Cracow Ms; ${ }^{77}$ some of them have their parallels in other German texts; ${ }^{78}$ and

5) some substantive features in the form of an amendment of an existing regulation ${ }^{79}$ or a legal term that is present in the Cracow Ms. ${ }^{80}$

Of all the features listed above, by far the most numerous are additions which augment a given a regulation. Their purpose is obvious: they adapt the text for practical needs. Their function is merely explanatory, and in no way do they seek to modify the meaning of the legal text. The best proof of that intention is the introduction of the definitions of agnate and cognate ${ }^{81}$ and the consistent use of these terms throughout the text. Occasionally, a German word is replaced by a descriptive phrase ${ }^{82}$ or adapted to the Polish realities. Thus the term 'Burggraf' (burgreve) is translated as 'castellan', but with little consistency. ${ }^{83} \mathrm{In}$

\section{See Table 2.1 .}

75 No. 3 (304), 49 (332), 6o (341), 65 (343), 106 (387), 156 (437), 197 (481), and 205 (490).

76 No. 46 (331) [BJ 170a], 59 (340) [MSR], 81 (363) [MSR and BJ 170a], 82 (364) [MSR and BJ 170a], 405 [BN 126о7], 220 (510) [BJ 168 and BJ 126о7].

No. 1 (302), 22 (313), 28 (318), 33 (320), $5^{2}$ (335), 58 (339), 62 (342), 82 (364), 83 (365), 91 (374), 93 (377), 102 (385), 119 (402), 120 (406), 141 (420), 166 (448), 169 (449), 195 (479) and 208 (495).

78 No. 22 (313) [MSR, BJ 17Oa], 35 (322) [BJ 168], 62 (342) [MSR, BJ 168, BJ 170a], 82 (364) [MSR, ВJ 170а], 110 (391), 418 [в 126о7].

79 No. 10 (309), 45 (330), 83 (365), 175 (453), 216 (501).

8 o No. $13,16,27,110(391), 185(469)$.

81 No. $166(448)$.

$82 \quad$ No. 499.

83 No. 13, 16, and 27. The word 'burgrave' is just co-opted into the Latin text in Articles 11 and 103; in Articles 82 and 98, it comes with an explanation that the term refers to the town of Magdeburg. The adoption of the term 'burgrave' in Poland is discussed by Inge Bily, "Die Rezeption des sächsisch-magdeburgischen Rechts in Osteuropa. Zum Analyseraster der Rechtstermini am Beispiel der Lexeme Burggraf und Lehen", in: Kanzleisprache - ein mehrdimensionales Phänomen: Tagungsband für Prof. PhDr. Zdeněk Masařik, DrSc., zum 8o. Geburtstag (Beiträge zur Sprachinselforschung), eds. Andrea Moshövel and Libuše Spáčilová (Wien, 2009), pp. 41-42. On the competences of burgraves in Magdeburg and Halle, especially their judicial functions, see Heiner Lück, "Das Gericht des Burggrafen von Magdeburg zu Halle an der Saale. Eine Skizze nach vorwiegend sächsichen Quellen”, in: Vertrauen in den Rechtsstaat. Beiträge zur deutschen Einheit im Recht. Festschrift für Walter Remmers, eds. Jürgen Goydre, Dietrich Rauschning, Rainer Robra, Hans-Ludlig Schreiber, and Christian Wulff (Köln - Berlin - Bonn - München, 1995), pp. 687-701; Gerlinde 
contemporary legal texts, the castellan was a royal office-holder with judicial powers over low-rank officials like the sottys (village head, scultetus). ${ }^{84}$ In the mid-14th century, when Konrad of Sandomierz was working on his translation of the Weichbild, the transformation of the local government in Małopolska into a system of smaller territorial units - each of them headed by a captain (starosta, capitaneus), whose deputy (podstarosta, vicecapitaneus), was also known as burgrave (burgrabia) - was in its early stages. It was accompanied by the strengthening of the institution of judicial districts centred on the castle

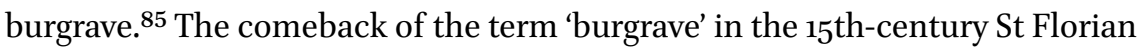
Ms may indicate an intention to readapt the terminology for higher-level court authorities to fit the new circumstances. Likewise, the omissions in the text by Konrad of Sandomierz are not the result of negligence and carelessness - so common when copying texts in the same language - but are instead consistent with a deliberate design. One example of such a design may be the modification of the provision concerning escheat to guarantee greater rights to the monarch. ${ }^{86}$ However, we must not assume that Konrad never made a mistake. For example, it is impossible to discern whether the change of the upper limit of the penalties imposed by the councillors from 36 to 30 shillings (solidi) was deliberate or was only a result of a mistake. ${ }^{87}$

Among the amendments modifying or extending the scope of a regulation, there is a description of the conditions to be met if a father were to replace his son in criminal proceedings. ${ }^{88}$ There are also some changes concerning women's rights. Konrad of Sandomierz omits the requirement for the husband's consent with regard to a deathbed gift. ${ }^{89}$ In clarifying the scope of the gerada, he extends the catalogue of items apportioned to women, even taking into account a wider catalogue of things which, after the wife's death, were supposed to serve the widower for daily use.${ }^{90}$ In two articles, he addresses the

Schlenker, "Das Magdeburger Burggrafenamt und Schultheißentum zu Halle/Salle", in: Hanse, Städte, Bünde. Die sächischen Städte zwischen Elbe und Weser um 1500. Ausstellung Kulturhistorisches Museum Magdeburg 28. Mai bis 26. August 1996. Braunschweigisches Landesmuseum. Ausstellungszentrum Hinter Aegidien 17. September bis 1. Dezember 1996, 1, ed. Matthias Puhle, (Magdeburger Museumsschriften) 4/1 (Magdeburg, 1996), pp. 129-130 and 132. See also Aleksander Zajda, Staropolska terminologia prawnicza (do 150o r.) [Polish Legal Terminology (until 1500)] (Kraków, 199o), p. 134.

$84 \quad$ No. 208.

85 Karol Nabiałek, Starostwo olsztyńskie od XIV do potowy XVII wieku [Captainship of Olsztyn from the 14th until the Middle of the 17th Century] (Kraków, 2012), pp. 59-64.

86 No. 156.

87 No. 10.

$88 \quad$ No. 58 and 59 .

89 No. 46.

90 No. 195 . 
problem of the axiological foundations of law and affirms the primacy of God's law and natural law. ${ }^{91}$ As the regulation that restricted the monarch by imposing a mandatory waiting period of one year and one day prior to coming into inheritance under the escheat law are left out, ${ }^{92}$ the regulations concerning servants are extended to include some sections from the Sachsenspiegel on the servant's liability for damage to his master's property and the principles of the master's liability for the acts of his servant..$^{93} \mathrm{~A}$ few more points may be added to this catalogue of the characteristic features of Konrad of Sandomierz's text from the discussion in Section 3.2 of the divergences from the Cracow MS common to the Gniezno Ms, the Baworowscy Ms, and the Działyńscy Codex IV.

\subsection{Divergences within the Texts of the versio Sandomiriensis}

The texts of the Sandomierz version are not uniform. Among its divergences from the Gniezno Ms, there are some that are common not only to the manuscripts of Group II, but also Group I. ${ }^{94}$ In all those cases, we can observe the remarkable consistency of the Działyńscy Codex I with the Gniezno Ms. The divergences from the Gniezno MS in the versio Sandomiriensis are shown in the following list:

1) the omission of the clause declaring municipal by-laws invalid unless they conform to God's law (No. 1);

2) the omission of the clause that only free men are eligible for the office of the sottys (scultetus) (No. 22);

3) consistent reinstatement of a phrase which was - seemingly accidentallyomitted in the Gniezno Ms concerning the master's obligation to pay his servant's wages (No. 6o);

4) the omission of the second part of the requirement that witnesses in property litigation must be (i) property owners (ii) whose right of possession is undisturbed (No. 93);

5) the addition to the provision concerning the disposal of property that gives the husband the right to alienate property acquired 'together with his wife' (No. 102);

6) the addition to the regulation concerning the inheritance rights of a grandson born to a female heir that transfers his right to inherit his grandfather's hergewet to the judge (No. 106);

7) the amendment reducing the number of oath-helpers from six to two in the action of debt (No. 175 and 216);

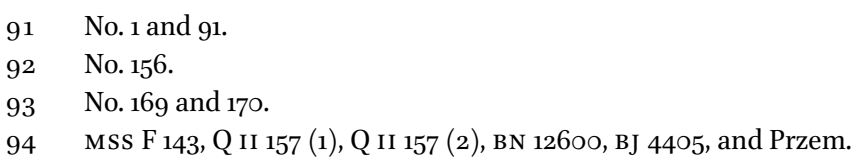


8) clarification of legal procedure: the judge may initiate summary proceedings without witnesses outside officially designated places in the action of debt (No 179); and

9) clarification of the rules of master-servant relations: if a master brings charges against his servant, the court cannot proceed without hearing the testimony of oath-helpers (No. 197).

Apart from an amendment which limits the scope of the regulation in Record 179, all of the modifications listed above can be found in texts of Group II.

Among the manuscripts of the versio Sandomiriensis, there is not a single pair whose texts would form a perfect match (i.e. 1oo per cent consistency). Hence, there is a reason to expect that Mikołaj of Cieszyn, the copyist of the Gniezno Ms, was an exception, and his text is fully consistent with his base, assuming that Mikołaj of Cieszyn used the autograph and not a copy. At any rate, it cannot be ruled out that the divergences listed above were originally consistent not only with the autograph by Konrad of Sandomierz, but also had parallels in the German texts. And, if we follow this line thought, we would expect the autograph to assign the hergewet to the judge in the case of the inheritance rights of a grandson born to a female heir (Record No.106 in the Appendix 2). It would contain the full wording of Article 24 on servants' wages, including the missing word, without which this provision became almost incomprehensible (No. 6o). Furthermore, in the original translation, there would be two short passages omitted in the Gniezno Ms (Nos. 102 and 179). Probably, it would also contain the requirement that two and not six oath-helpers are sufficient to proceed in the action of debt, although the manuscripts are not wholly consistent on this point (Nos. 175 and 216). For what it is worth, this conjectural analysis certainly helps us to trace the bifurcation in the family tree of Group I. It also strengthens the claim that two variants of Konrad of Sandomierz's Latin translation were produced: one which reproduced the alterations (defects) characteristic of the Gniezno Ms, and another one (now lost) which either had either only a few of those alterations or perhaps even none at all.

\subsection{Summary: Adaptation of the Magdeburg Law by Means of the Latin Translation}

The Latin translation of the Weichbild was an archetype of the Sandomierz version of the Silesian-Małopolska compilation. An examination of the extant sources suggests that Konrad did not produce a one-to-one translation. First, his base text could not have been solely the Cracow Ms (BJ 169) or its copy, because the Latin text differs significantly from MS BJ 169. It has now been proven that those divergences match the text of other German-language versions of the Weichbild. Consequently, it can be surmised that Konrad of 
Sandomierz used another manuscript for his translation, in addition to the Cracow Ms, which shared the characteristic features of the Magdeburg Bench Law and the Wawel manuscript (MS BJ 168).

Konrad of Sandomierz's work was not a plain translation, but instead, an original Latin version of the Saxon-Magdeburg Law. Not only did he use more than a single base text, but he also supplemented the Weichbild with some regulations from the Sachsenspiegel and the Legal Instructions for Wroctaw (1261). He expanded the received text with explanations and clarifications. He adapted the wording of the provisions to contemporary realities of the Kingdom of Poland in the 14th century, and he rearranged the order of the articles. It seems that all those alterations and editorial interventions had one purpose: to make the Weichbild as understandable and useful as possible for its users.

Konrad of Sandomierz's work must have been produced before 1359, the date of Mikołaj of Cieszyn's Gniezno manuscript, the earliest extant copy of the versio Sandomiriensis. It was that version that was continually modified in the process of transmission. The differences between subsequent copies accumulated, but they did not obliterate a family identity of texts like Mss Gn., Dział. I, Przem., Plesz., and Boz (group A) and MSs F 143, Q II 157 (2)/BN 126oo, Q II 157 (1), and BJ 4405 (group B).

This analysis is largely technical, but it also allows us to develop a better view of Konrad of Sandomierz's achievement, a combination of solid scholarship and pragmatism. The popularity of the Sandomierz version of the Weichbild, which soon eclipsed the German texts of the Silesian-Małopolska compilation, was no doubt related to a demand for a text in Latin, the language of the law in medieval Poland. If the success of the Sandomierz version was so assured, it begs the question: what were the reasons for the growth of another branch of the Weichbild tree from the Group II?

\section{Group II: Versio Cracoviensis}

\subsection{Conformity with the German Text}

The Latin Weichbild, included in Group II, is characterized, in opposition to the texts of the Sandomierz version, by formal features that are common to the German manuscripts (Section 1). Furthermore, according to statistical calculations, divergences in Group II texts from the Gn. Ms vary between 33 per cent and 40 per cent. A comparison of the articles in the Baworowscy MS with the German texts provide further data which throws into relief the differences between both Groups I and II. The aggregate results are presented in Table 16. ${ }^{95}$

It does not take account of the additions from the ortyle in the Baworowscy Ms. 
TABLE 16 Divergences in the Latin translation in the Gniezno MS (Gn.) and the Baworowscy MS (BN 12607)

1. Divergences from the German texts, common to MS Gn., MS BN 12607 $72^{\mathrm{a}}$ and Ms Dział. IV

2. Divergences from MS BJ 169 common to MS Gn., MS BN 12607 and MS $17^{\text {b }}$ Dział. IV, justified by conformity with other German texts

3. Divergences from the German texts, common to MS Gn. and MS BN $12607 \quad 19^{\text {c }}$ absent from Dział. IV

4. Divergences from German texts in MS BN 12607 absent from Ms Gn. $\quad 34^{\mathrm{d}}$

5. Conformity of MS BN 12607 with the German texts where MS Gn. displays $29^{\mathrm{e}}$ a divergence

6. Conformity of MS BN $126 \circ 7$ exclusively with MS BJ 168 where MS Gn. $\quad 1^{\mathrm{f}}$ displays a divergence from the German texts

7. Conformity of MS BN 12607 exclusively with the German text in MS BJ $\quad 1^{\mathrm{g}}$ 12607 where Ms Gn. displays a divergence from the German texts

8. Alteration of wording in MS BN 12607 which in MS Gn. is consistent with $\quad 2^{\text {h }}$ MS BJ 169 to a wording consistent with MS BJ 168/MSR

9. Alteration of wording in MS BN 12607 which in MS Gn. is consistent with $\quad 3^{\mathrm{i}}$ MS BJ 169 to a wording consistent with MS BN 12607 Ger.

10. Alteration of wording in BN 12607 which in MS Gn. is consistent with MS $\quad 1^{\mathrm{j}}$ BJ 168 to a wording consistent with MS BJ 169

11. Alteration of wording in BN 12607 which in MS Gn. is consistent with MS $\quad 1^{\mathrm{k}}$ BJ 168 to a wording consistent with MS BN 12607 Ger.

12. Alteration of wording in $\mathrm{BN} 12607$ which in MS Gn. is consistent with MS $\quad 4^{1}$ BJ 17Oa/MSR to a wording consistent with MS BJ 169/BN 12607 Ger.

a Cf. Section 3.2.

b See ibidem.

c No. $383,402,406,409,440,442,443,445,45^{2}, 456,458,462,477,478,486,490,493,494$, and 497 .

d No. 303, 306, 311, 312, 316, 362, 367, 378, 379, 380, 391, 392, 413, 414, 416, 419, 425, 429, 433, 434, $435,438,45 \circ, 465,468,470,480,483,484,489,495,496,500$, and 507 .

e No. 302, 304, 309, 318, 320, 330, 335, 339, 341, 368, 371, 375, 385, 394, 395, 411, 437, 448, 449, 451, $453,459,463,474,479,492,498,499$, and 5 o1.

f No. 365 .

g No. 503 .

h No. 352 and 36 o.

i No. 400,436 and 460 .

j No. 510 .

k No. 322 .

l Nos. 331, 342, 363 and 364 . 
The divergences from the German texts that are common to the Gniezno Ms, the Baworowscy MS, and the Działyńscy Codex IV (Items 1 and 2) have already been discussed in Section 3.2. There are as many as 72 of them. There is also a group of 19 divergences which are common exclusively to the Gniezno manuscript and the Baworowscy ms (Item 3; they are absent from the Działyńscy Codex IV). Notably, these alterations - usually phrases of no more than a few words - do not affect the meaning of the regulations. ${ }^{96}$

In almost 30 cases, the given manuscript remains consistent with the German texts, while the matching portions of the text in the Gn. Ms display divergences (Item 5). Furthermore, in the Baworowscy Ms, there is only one case of conformity with the Wawel Ms (Item 6) and another such case with the German text in MS BN 12607 (Item 7). It should be borne in mind, however, that in six cases, a departure from the Gniezno Ms does not necessarily signify a departure from Konrad of Sandomierz's autograph (for the discussion of that manuscript, see Section 4.3) ${ }^{97}$ In 12 cases, the wording of the Gniezno Ms that conformed with one group of German texts was altered to conform with other German texts (Items 8-12).

The conformity of the Baworowscy Ms with the German texts concerns minor points ${ }^{98}$ as well as issues of considerable importance. Let us take a brief look at a few of these issues. Similarly to the German texts, MS BN 12607 does not carry Konrad of Sandomierz's additions concerning the servant's liability for his master's lost property, the master's liability for a horse stolen from his servant, ${ }^{99}$ the conditions attached to the instrument of proxy in criminal proceedings, ${ }^{100}$ the requirement of compliance of laws enacted by the councillors with God's law, ${ }^{101}$ or the affirmation that the right to inherit property

96 Only in three cases does the text of MS Gn. and MS BN 12607 - while deviating from the wording of the German texts - introduce a new quality. In No. 408, it is made clear that the disability claimed in connection with the appointment of a proxy could be either physical or mental. In No. 49o, the removal of the clarification that the procedure required the presence of two jurymen might have led to uncertainty about their minimal number. In No. 495, the provision is extended: action against the sottys could now be brought either before a wójt or before a castellan. However, in No. 402, the use of the narrower term 'to poison' instead of 'to kill' in the context of the whole provision does not change the regulation.

The autograph of Konrad of Sandomierz's translation could be consistent with the German text in 6o (341), 102 (385), 106 (387), 175 (453), 179 (459), and 216 (501).

$98 \quad$ No. 304, 335, 368, 394, 411, 462, 474, and 479 .

99 No. 449.

$100 \quad$ No. 318.

$101 \quad$ No. 302. 
from a relative is a natural right. ${ }^{102}$ In the Baworowscy Ms, as in the German texts, there is no definition of paternal and maternal relatives. ${ }^{103}$ Moreover, the Group II text is consistent with the German text in its wording of the provisions concerning escheat ${ }^{104}$ and the gerada $;{ }^{105}$ it also includes the requirement, omitted in the Gniezno Ms, concerning the husband's consent to his wife's mortis causa gift (made by her in expectation of impending death). ${ }^{106}$ Nor does MS BN 12607 contain the errors of MS Gn., such as the incorrect figure for the penalty set for breaching the weights and measurements regulations ( 30 instead of 36 shillings). ${ }^{107}$

Many of them, however, are individual features which are peculiar to MS BN 12607/Oss. ${ }^{108}$ Beside some minor alterations, ${ }^{109}$ the Baworowscy Ms contains a definition of public holidays ${ }^{110}$ and a clarification of the requirement concerning the number of oath-swearers in cases of wounding. ${ }^{111}$ The text is not free from errors, such as the introduction of the term cognatus, where the German text speaks of paternal relatives. ${ }^{112}$

Group II texts also include the provisions omitted by Konrad of Sandomierz. These are the final articles of the Constitution of Courts, appended to the Jewish oath. This is another piece of evidence that the translation was done by the author of this version.

\subsection{Divergences in the Wording of the Provisions and Vocabulary}

While Konrad of Sandomierz's translation was used in developing the text of Group II, some provisions are completely new, even though they are consistent with the German text. It includes also a number of articles whose regulations are consistent with the German base, both in the Sandomierz version and in Group II, but their wording is completely different. Table 17 presents representative examples of the latter from both versions.

In the first two examples, the translation of the German text is correct in both versions. The corresponding Latin texts are virtually identical except for a few details. The main difference is the use of a different term in the Latin

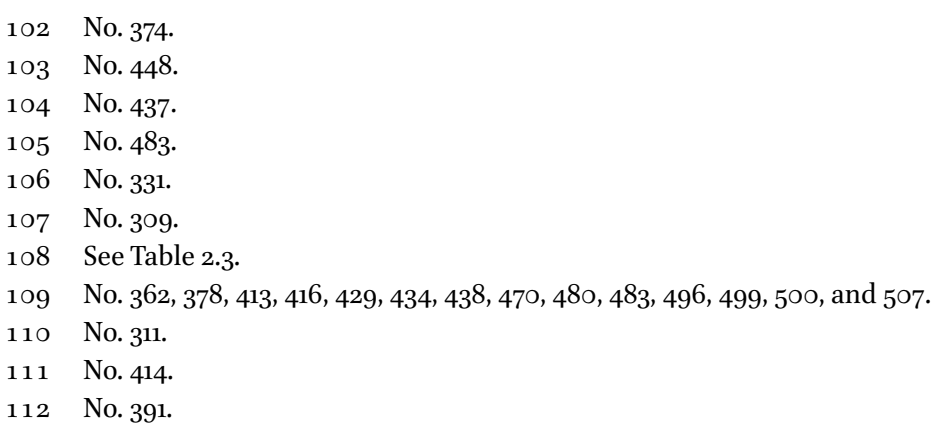


TABLE 17 Notable divergences from the German base in the wording of some provisions in Gniezno MS (Gn.) and Baworowscy Ms (BN 126o7)

\begin{tabular}{|c|c|c|c|}
\hline & $\begin{array}{l}\text { MS BJ 169, MS BN } \\
126 \circ 7\end{array}$ & MS Gn. & MS BN 12607 \\
\hline $\begin{array}{l}\text { 1. Control on } \\
\text { terminology }\end{array}$ & $\begin{array}{l}{[16 \S 1] \text { Swaz so ein man }} \\
\text { gibit undir banne besitzit } \\
\text { he damit iar und tac ane } \\
\text { rechte widir sprache, daz } \\
\text { ist he neher zcu behalden } \\
\text { mit dem richtere und mit } \\
\text { den sheppfen, den iz im } \\
\text { iener untfuren muge. }\end{array}$ & $\begin{array}{l}{[16 \S 1] \text { Quitquit }} \\
\text { masculus dat sub } \\
\text { banno, si possidebit } \\
\text { pacifice et quiete absque } \\
\text { arestacione aliqua anno } \\
\text { et die, hoc propius et } \\
\text { melius optinere potest } \\
\text { cum iudice et scabinis, } \\
\text { quam ab ipso aliquis } \\
\text { possit exbrigare. }\end{array}$ & $\begin{array}{l}{\left[\begin{array}{ll}16 & \S \\
1\end{array}\right] \text { Quidquid masculus }} \\
\text { dat sub banno, si possidebit } \\
\text { pacifice ac quiete absque } \\
\text { contradiccione anno et } \\
\text { die, hoc proprius ac melius } \\
\text { obtimere potest cum iudice et } \\
\text { scabinis, quam aliquis ab ipso } \\
\text { possit exbrigare. }\end{array}$ \\
\hline $\begin{array}{l}\text { 2. Changes } \\
\text { in the order } \\
\text { of phrases }\end{array}$ & $\begin{array}{l}\text { [33] Wunden sich zwene } \\
\text { undir ein andir, der } \\
\text { eine mit einem swerte, } \\
\text { der andir mit einem } \\
\text { mezzere, ob di wunden } \\
\text { kamfwertic sin, deme } \\
\text { mit dem swerte get iz an } \\
\text { di hant, deme mit dem } \\
\text { mezzere get iz an den } \\
\text { hals, wend daz mezzir } \\
\text { ein duplich mort. }\end{array}$ & $\begin{array}{l}\text { [33] Quod si se duo } \\
\text { mutuo vulneraverint } \\
\text { unus cutello et alter } \\
\text { gladio, et sivulnera } \\
\text { utriusque monomachalia } \\
\text { fuerint, illi cum gladio } \\
\text { solvit manum, illi cum } \\
\text { cutello solvit collum, quia } \\
\text { cutellus furtivam infert } \\
\text { mortem. }\end{array}$ & $\begin{array}{l}\text { [35] Quod si se duo mutuo } \\
\text { vulneraverint unus gladio, } \\
\text { alter cultello, et si vulnera } \\
\text { utriusque monomachalia } \\
\text { fuerint, illi cum gladio solvit } \\
\text { manum, illi cum cultello solvit } \\
\text { collum, quia cultellus furtivam } \\
\text { infert mortem. }\end{array}$ \\
\hline $\begin{array}{l}\text { 3. New } \\
\text { translation }\end{array}$ & $\begin{array}{l}\text { [64] Ob sich ein erbe } \\
\text { virstirbit, daz sich nyman } \\
\text { dar zcu zcuhit mit rechte } \\
\text { binnen iare und tage, } \\
\text { daz nimit di kunicliche } \\
\text { gewalt. }\end{array}$ & $\begin{array}{l}{[66] \text { Quod si hereditas }} \\
\text { mortaliola }[s] \text { absque } \\
\text { heredibus inventa seu } \\
\text { reperta fuerit, regie cedet } \\
\text { maiestati. }\end{array}$ & $\begin{array}{l}\text { [71] Quod Si hereditas } \\
\text { mortaliola }[s] \text { absque sine } \\
\text { heredeibus inventa fuerit } \\
\text { aut remanserit anno et die, } \\
\text { seu reperta fuerit regie cedet } \\
\text { maiestati. }\end{array}$ \\
\hline $\begin{array}{l}\text { 4. New } \\
\text { wording/new } \\
\text { translation }\end{array}$ & $\begin{array}{l}{[101] \text { Lage und daz }} \\
\text { man vrowen notet } \\
\text { und heimsuche richtet } \\
\text { der burcgreve und } \\
\text { andirs niman, der } \\
\text { shultheize nicht. Mac } \\
\text { man di heimsuche }\end{array}$ & $\begin{array}{l}\text { [103] Obsidia et quod } \\
\text { femine stuprantur, } \\
\text { et irruenciam } \\
\text { domiciliorum, burgravius } \\
\text { iudicat et nullus alter nec } \\
\text { scultetus. Si irruencia } \\
\text { domicilii probabiliter }\end{array}$ & $\begin{array}{l}\text { [107] Obsidia Insidias } \\
\text { et stupraqudfemine- } \\
\text { stuprantur et domorum } \\
\text { irruenciam, tomicitiorum } \\
\text { burgrabvius iudicat et nullus } \\
\text { alter nec eciam scultetus. Si } \\
\text { domorum irruencia tomicitit }\end{array}$ \\
\hline
\end{tabular}


TABLE 17 Notable divergences from the German base (cont.)

\begin{tabular}{|c|c|c|}
\hline $\begin{array}{l}\text { MS BJ 169, MS BN } \\
\text { 126o7 }\end{array}$ & Ms Gn. & MS BN 126o7 \\
\hline $\begin{array}{l}\text { bewisen mit wunden } \\
\text { und mit gewundetem } \\
\text { gezcimmere, hat ein } \\
\text { man des den richter } \\
\text { und di shreiliute zcu } \\
\text { gezcuge, iener ist im } \\
\text { neher zcu antwurten mit } \\
\text { eime campfe, wan he im } \\
\text { entgen muge mit siner } \\
\text { unshult. }\end{array}$ & $\begin{array}{l}\text { potest ostendi cum } \\
\text { vulneribus et cum } \\
\text { vulneratis edificiis, si } \\
\text { super hoc iudicem et } \\
\text { homines, qui clamorem } \\
\text { audierunt, habere } \\
\text { potuerit in testimonium, } \\
\text { oportet desuper } \\
\text { respondere cum duello, } \\
\text { quam cum iuramento } \\
\text { evadere possit. }\end{array}$ & $\begin{array}{l}\text { probabiliter potest ostendi } \\
\text { potest cum vulneribus vel } \\
\text { etcum edificio vulneratois } \\
\text { edificits, si super hoc iudicem } \\
\text { et clamatores homines qui } \\
\text { etamorem audtierunt habere } \\
\text { potuerit in testimonium } \\
\text { poterit habere, extunc ille } \\
\text { propius sibi oportet de super } \\
\text { respontere cum duello debet } \\
\text { respondere, quam ille suo } \\
\text { possit evadere, quod cum } \\
\text { iuramento. evadere possit. }\end{array}$ \\
\hline
\end{tabular}

texts of Article 16: in the Gniezno Ms, it is arrestatio, whereas the Baworowscy Ms has contradictio, which is closer to the German base. As the term arrestatio constitutes a significant alteration of the German base, it could not have been anything other than deliberate. Article 33 in the Gniezno Ms is almost consistent with the Cracow manuscript. The wording in the Baworowscy Ms retains the word order of the German base in 'sword' and 'knife' (swerte ... mezzere / gladio ... cultello), as well as their direct juxtaposition, without the linking et (as in the Gniezno Ms). All these details suggest the author of the Cracow version must have looked up the text of the Sandomierz version, checked it against the German base, and finally introduced alterations that he thought appropriate. However, in some provisions, the alterations go further than that. Such farreaching interventions into the received text may have been due to the need to adapt a regulation to the German wording (Item 3 ) or to the fact that the provision could do with a better wording (Item 4 ). The provisions that have been much redacted include Articles 4, 5, 25, 26, 37, 38, 40, 48, 56, 65, 66, 75, 76, 83, 91, $94,102,103,104,106,107,108$, and 109. ${ }^{113}$ In fact, there is not a single article with identical wording in the Gniezno MS and the Baworowscy MS.

113 According to Ms Gn. numbering scheme. 
TABLE 18 Differences of vocabulary in selected Latin texts of the Weichbild

\begin{tabular}{|c|c|c|c|c|}
\hline $\begin{array}{l}\text { Article in } \\
\text { Ms Gn. }\end{array}$ & Gniezno Ms & $\begin{array}{l}\text { Baworowscy Ms, } \\
\text { Opatów Ms, Żagań Ms }\end{array}$ & $\begin{array}{l}\text { Działyńscy } \\
\text { Codex IV }\end{array}$ & Statutes \\
\hline 6 & legalitas & bannum & legalitas & legalitas seu bannum \\
\hline 39 & suspendium & patibulum & patibulum & $\begin{array}{l}\text { patibulum sive } \\
\text { suspendium }\end{array}$ \\
\hline 46 & apparatus & fundus & apparatus & fundus seu apparatus \\
\hline $\begin{array}{l}50,61 \\
74,96\end{array}$ & tutor & tutor & mundiburdius & tutor \\
\hline 53 & advocatus & advocatus & prolocutor & advocatus \\
\hline 79 & probus & fidedignus $^{\mathbf{a}}$ & fidedignus & fidedignus \\
\hline 101 & munera & munera & dona & munera \\
\hline 102 & $\begin{array}{l}\text { homines qui } \\
\text { clamorem audierunt }\end{array}$ & clamatores & clamatores & clamatores \\
\hline 103 & $\begin{array}{l}\text { homines qui } \\
\text { clamorem audierunt }\end{array}$ & clamatores & clamatores & $\begin{array}{l}\text { homines qui } \\
\text { clamorem audierunt }\end{array}$ \\
\hline
\end{tabular}

a The terms fidedignus, 'trustworthy', and probus, 'honest' are rendered in Polish as ludzie dobrzy, 'good people'. Cf. Zajda, Staropolska terminologia prawnicza (do 150o r.), p. 121.

Apart from alterations of content and wording, the texts in both groups quite often do not use the same words and terms. The differences in vocabulary are shown in Table 18.

It is worth noting that in the Baworowscy Ms, Article 5 refers to legittime impedimentum, where all other manuscripts have legale impedimentum; in Article 30, instead of banca, it has scampna scabinalia (as in a gloss of the Leipzig manuscript); in Article 32, mercenarius is replaced by famulus; in Article 56, we can find scabini instead of iurati; and in Article 96, anni discrecionis (as in the Opatów Ms) is present in lieu of anni pubertatis. As Table 18 shows, the vocabulary used in the Statutes draws on both the Gniezno and the Baworowscy manuscripts. Meanwhile, in the Działyńscy Codex IV, we can find terms borrowed from both groups, as well as new constructs. Generally, such vocabulary substitutions did not count as modifications of the legal regulations.

\subsection{Circumstances of the Composition of the Cracow Version}

There can be no doubt that the Group II manuscripts constitute a different version of the Latin Weichbild. This is demonstrated by the distinct array of 
their formal features, namely, the list and arrangement of the articles, the contents of the provisions, the use of the German texts, and the additions from the Magdeburg ortyle in a number of manuscripts. Earlier, Konrad's versio Sandomiriensis has been identified as a good piece of work. Why then, it may be asked, would anybody go to the trouble of doing that work all over again and preparing another version of the Latin Weichbild? Perhaps, one might conjecture, the discrepancies between Konrad's text and the German Weichbild were noticed, and the dismay led to the commissioning of a new, more accurate translation. This must have taken place soon after Konrad completed his work, as the features characteristic of this new version appear for the first time in the St Petersburg MS (F 143) dated 1368, nine years earlier than the earliest extant text of the 1359 Sandomierz version.

Once this scenario is granted, another question must be asked, as well. Was this new version actually a new translation, or merely a revised redaction of the previous one? The author of the new version clearly made use of Konrad of Sandomierz's text, but he, too, consulted the earlier translation by Konrad of Opole while translating the Sachsenspiegel. ${ }^{114}$ In other words, the use of an earlier text is not a strong enough argument to deny a new translation its 'newness' (even though, in a somewhat similar research project, the detection in Jacques Gohory's translation of Machiavelli's Il Principe of longer phrases identical to those in an earlier translation by Guillaume Cappel was thought to be sufficient to write off the former as a piece of plagiarism). ${ }^{115}$

Admittedly, the crux of the matter is that that we know neither the autograph of Konrad of Sandomierz's translation, nor the archetype of the new version. Additionally, the reconstruction of the features of the base texts that would have to be shared by the extant German manuscripts and Konrad of Sandomierz's translation and - conjecturally - the new version is anything but fragmentary. However, as the comparative analysis presented above indicates, the scope of the use of the German base texts was different in both the versio Sandomiriensis and the new version, which has relatively few phrases characteristic of the Magdeburg Bench Law and the Wawel Ms. Hence, the new version had a different base text and cannot not be regarded as a revised copy of

114 Rymaszewski, Lacińskie teksty Landrechtu Zwierciadta Saskiego w Polsce. Versio, pp. 85-88. 115 Jean-Claude Zancarini, "Uno Picolo Dono: A Software Tool for Comparing the First Edition of Machiavelli's The Prince to Its Sixteenth Century French Translations", in: The Radical Machiavelli. Politics, Philosophy and Language, eds. Filippo Del Lucchese, Fabio Frosini, and Vittorio Morfino (Leiden - Boston, 2015), pp. 52-53, and esp. the samples in Table 2.3, p. 47. 
Konrad of Sandomierz's translation. ${ }^{116}$ Therefore, to summarize, the author of the new version:

1) gave it a formal coherence with the German text of the Silesian-Małopolska compilation, that is, he removed the additional provisions of versio Sandomiriensis and added the provisions of the Constitution of Courts that had been omitted by Konrad of Sandomierz, as well as Article 76;117

2) made some alterations in the text from the versio Sandomiriensis after checking another German base; and

3) re-edited numerous provisions by giving them a new wording which was different from that of the Sandomierz version; practically all the articles were given a new redaction.

What this summary makes clear is that the new version was not just a revised copy of Konrad of Sandomierz's translation, even if it depended on its predecessor to a significant extent.

The creation of the text used in the Częstochowa ms, the Kielce Ms, the St Florian MS, the Działyńscy Codex IV, and the Warsaw Ms did not mean that the translation was complete. The next stage was the supplementation of the Latin Weichbild with additions from the ortyle. ${ }^{118}$ For those who contemplated the task of incorporating the ortyle into the Weichbild, the new version offered the obvious advantage of being consistent with the German text of the Silesian-Małopolska compilation. The evidence that the German ortyle were taken from a collection associated with Cracow and embedded into a German text dependent on the Cracow manuscript does exist (see Chapter 1). The well proven connection with Cracow also justifies the use of the term 'Cracow version' for the branch of the Weichbild which includes the Baworowscy Ms, the

116 Otto Kade's classic definition of translation emphasizes the process of striving to render the original text. See: Mary Snell-Hornby et al. eds., Handbuch Translation (Tübingen, 1998), p. 37. However, if each version had a different base, the claim that Version B was merely a revised (improved) copy of the original translation must be rejected. After all, it is a commonplace of medieval translation studies that the creation of a translation was as often as not based on more than one any basic text. This observation is fully confirmed by the work done on the Latin translation of the Weichbild. See: Section 137 "Relationships between Text and Translation in Medieval Europe", in: Translation. An International Encyclopedia of Translation Studies, 2, eds. Harald Kittel, Armin P. Frank, Norbert Freiner, Theo Hermans, Werner Koller, José Lambert, Fritz Paul (Berlin - New York, 2007), p. 1298; cf. Theo Hermans, What is (not) Translation?, in: The Routledge Handbook of Translation Studies, eds. Carmen Millán and Francesca Bartina (London - New York, 2013), pp. 75-76.

117 According to the numbering scheme of the Cracow MS (BJ 169).

118 As is argued in Chapter 1, the inclusion of the ortyle in the Latin text could not have happened before they were incorporated into the German texts. 
Opatów Ms, the Żagań ms, and the lost Sanok manuscript, even though some of them contain the ortyle, while others do not. The authors of the manuscripts without the ortyle, as well as those who translated them and included them in the Weichbild, remain anonymous. Unfortunately, the clues that might enable us to trace them are missing.

\subsection{Summary: New Characteristics, a New Version}

The Cracow version must have been created prior to 1368 , the date of the earliest manuscript (Petersburg MS F 143) with a text that displays the characteristic features of that version. Its author relied chiefly on the Sandomierz version, but allowed himself to be influenced by the text of the Cracow version.

The unknown author of the Cracowversion also used Konrad of Sandomierz's Latin Weichbild as his base. Yet, in contrast to his predecessor, his concern was first and foremost with producing an accurate translation of what he thought was the authentic legal text. This assessment is based on the following facts. First, he translated and included in his work all those provisions of the German Weichbild that had been left out by Konrad of Sandomierz. Second, the wording of many provisions in his work differs markedly from that of Konrad. Third, he revised and pruned Konrad's text wherever it diverged from the German base, but, at the same time, introduced alterations of his own. Fourth, he drew on a greater range of German texts than did other authors working with the Sandomierz version.

The effort expended to bring the Latin Weichbild into conformity with its original German text and the freedom with which its anonymous author/ translator introduces his own solutions at every level of text construction are the two key characteristics of the Cracow version. The latter stands in the way of treating the Cracow version as a revision, committed to a higher standard of accuracy and exactitude, of the old versio Sandomiriensis. The term 'Cracow version' is intended to mark its special position, determined by its affinities with the German-language Cracow manuscript (MS BJ 169) and its augmentation by an array of Magdeburg ortyle from a collection associated with Cracow.

The differences between the two versions named after Sandomierz and Cracow were hardly the result of cautious marginal tinkering, and the gap grew wider in the process of transmission. The Cracow version is probably older than its Latin form. It came into being when a conjectural German-language Weichbild was augmented with a set of ortyle in a manner which resembles the disposition of German texts (for a detailed argument, see Chapter 1). Later, manuscripts that stemmed from the Cracow version show a tendency to introduce daring editorial modifications (like changing the wording of provisions or 
excising whole articles). In this study, manuscript texts of the Cracow version that unequivocally represent that trend are grouped together under the label of 'the Wawel variant'.

\subsection{Alterations within the Cracow Version}

The texts of the Weichbild in the Działyńscy Codex IV and the Warsaw MS are remarkably similar, even if this is not obvious from the columns of figures in our quantitative analyses. The reason for this is simple: the statistical count is distorted by the fact that a large portion of the Warsaw ms has been destroyed. Therefore, in effect, our analysis of the ms Warsz./Ms Dział. IV pair has to depend on the latter, which - to complicate things further - includes a section entitled In Colmensi with a selection of provisions of the Chelmno Law (Der Alte Kulm). Nevertheless, the formal features of both texts leave hardly any doubt about their affiliation. They belong to the manuscripts of the Cracow version, a fact further borne out by statistical calculations based on the data in Appendix 2. This data indicates that the Działyńscy Codex IV, like other members of that group, departs significantly from Gniezno ms. What sets it apart from the Baworowscy MS (BN 12607), Opatów MS (Oss.) and Żagań MS (II Q 4) is that it does not include the ortyle - which needs to be taken into account in interpreting its lower number of divergences, prima facie, from the Gniezno Ms than is the case with the other manuscripts. The divergences from the Gniezno Ms in the Działyńscy Codex IV are principally of two kinds: individual alterations and omissions of whole provisions. Finally, the affiliation of MS Dział. IV/MS Warsz. with the Cracow version is confirmed by a comparison of the linguistic shape of more than a dozen provisions in the Działyńscy Codex IV and the Baworowscy Ms; the wording is very similar in the two texts and significantly different from that of Gniezno Ms. ${ }^{119}$

The comparative analysis of the data in Appendix 3 reveals that the author of the Działyńscy Codex IV made use of other manuscripts than the one containing the Cracow version. Therefore, for instance, his text has parallels with that of the Sandomierz version (the Gniezno Ms). Although the Cracow version was his base text, he took over the whole of Article 37 from the versio Sandomiriensis. There is also other evidence to confirm that he had both

119 Articles 2, 4, 9, 25, 35, 39, 40, 70, 72, 75, 83, 92, 102, 105, 106, and 107. Cf. also the parallels between the Baworowscy ms and the Działyńscy Codex IV in Records 318, 331, 341, 352, $425,442,450,499,500,504,507$, and 510 . 
versions at his disposal. ${ }^{120}$ Furthermore, as already mentioned, the Działyńscy Codex IV omits the articles which are absent from the Wawel Ms (BJ 168) and, what is more, spells out the reasons for such omissions, as does MS BJ 168 . Moreover, we can find seven cases where the Latin text is consistent exclusively with the German-language Wawel manuscript (Table 15$) \cdot{ }^{121}$ At least six of these cases are direct borrowings from the Wawel Ms. ${ }^{122}$ In the remaining three cases, the divergences from the Gniezno Ms comply with the text of MS BJ $17 \mathrm{Oa}^{123}$ or the Baworowscy MS - probably the result of the influence of the Wawel Ms. ${ }^{124}$ Thus, we may conclude that the author used both the Cracow and Sandomierz versions, and on top of that, consulted a text consistent with MS BJ $168 .{ }^{125} \mathrm{He}$ also introduced a number of individual changes which have no parallel in other Latin or German texts. Another feature of the Działyńscy Codex IV is its pronounced stylistic make-up due to the author's preference for shorter phrases and his concern for making the regulations as clear as possible. ${ }^{126} \mathrm{He}$ is in the habit of supplanting descriptive phrases with legal terms with medieval connotations. For example, he abbreviates der uf den man clagit ('the one against whom the complaint is brought') to a single word, reus, 'defendant,'127 and replaces the word tutor ('guardian') with mundiburdius (Articles 50, 61, 74, and 96), ${ }^{128}$ advocatus with prolocutor in Article 53, and munera with dona in Article 101. Sometimes, however, he chooses a general term if it is more apt. For example, instead of translating silbir literally as argentum, 'silver', he opts for pecunia ('money'). ${ }^{129}$ His close attention to language does not render his translation fool-proof, as shown in the substitution

120 This is proven by Records 374 and 453, which indicate that the text in the Działyńscy Codex IV is a synthesis of the Gniezno Ms and the Baworowscy Ms, while Records 318, $36 \circ, 363,364$, and 460 are consistent with Ms Gn. but at odds with the Baworowscy Ms.

121 No. $322,352,436,461,472$, and 506.

122 In one case, we can find a parallel between the Działyńscy Codex IV / the Gniezno Ms and the Wawel Ms (No. 322).

123 No. 331.

124 No. 404 and 408.

125 The only case of conformity with MS BJ 170a consists of the omission of a passage in Article 1 (No. 305); it is probably simply a copyist's error.

126 No. 301, 322, 431, 432, 471, 475, 479, 498, and 499. See also Nos. 318, 324, 356, and 438.

127 No. 429; cf. also No. 499 .

128 For an analysis of the use of term opiekun, 'guardian', in Polish legal terminology, see: Aleksander Zajda, Studia z historii polskiego stownictwa prawniczego i frazeologii [Studies in the History of Polish Legal Terminology and Phraseology] (Kraków, 2001), pp. 46-51. He argues that the word tutor entered the Polish language in the 16th century and functioned alongside the accustomed opiekun and the now-obsolete opiekadlnik (also in the sense of 'fiduciary').

129 No. 469. 
of selbe sibende with cum septem testibus, ${ }^{130}$ a mistake which results in raising the number of oath-swearers from six to seven. Some changes also had practical consequences.

\subsection{Practical Effect of the Alterations in Dziatyńscy Codex I $\mathrm{V}^{131}$}

Further details were added to the regulations that concerned evidentiary proceedings, in both civil and criminal cases. The requirement specifying the number of oath-swearers in two provisions concerning debt payment was limited to two. ${ }^{132}$ At the same, the requirement specifying the number of oath-helpers in disputes over land inheritance was reduced from six to two. ${ }^{133}$ The trial of a person caught in the act would, under a new dispensation of the Działyńscy Codex IV, require the participation of six oath-helpers, ${ }^{134}$ while in cases of rape, assault, burglary, murder, theft, or robbery, their number was reduced to was reduced to two (mettertius) in order to proceed more efficiently with these types of crime. ${ }^{135}$ Similarly, should the plaintiff in the action of murder choose to forego his right to precedence in presenting evidence, the defendant could be allowed to clear himself of the charges by the oaths of two rather than six compurgators. It seems that the goal of these alterations was to speed up the litigation and to discipline the complainant. ${ }^{136}$ The Działyńscy Codex IV also contains a definition of a duel ${ }^{137}$ and an amplified formula of the Jewish oath, the latter modelled on the German text in the Wawel Ms. ${ }^{138}$ All of the modifications introduced by the author of Ms Dział. IV are sensible and pragmatic.

In line with the tendency we have established in the Cracow version, the Działyńscy Codex IV also drops the term 'agnate' in favour of the more general term 'cognate' (i.e. a blood relative). ${ }^{139}$ The omission of the reservation that the deceased's property may not be inherited by his children who were previously excluded from the inheritance means that they are included in the

\footnotetext{
$130 \quad$ No. 338.

131 See also, in connection with the profile of the Działyńscy Codex IV presented here in greater detail, Nos. 78, 84, 114, 119, and 188.

132 No. 175 and 177. The amendments made the provisions more specific, e.g. 'debt' was narrowed down to 'pecuniary debt' (No. 178), and the payment of debt should be made in 'money that is used in payments nowadays' (No. 181).

133 No. 92.

134 No. 118.

135 No. 113 .

$136 \quad$ No. 83 .

137 No. 71.

138 No. 509 .

139 No. 79.
} 
distribution of the estate. ${ }^{140}$ Presumably, this would mean in practice that the disproportionally privileged heirs would have to give up some of their assets to their siblings now that the claims of those with no stake in the estate could be recognized.

The omission of the sottys (scultetus) from the institutional authorities with jurisdiction over burghers was a concession to the Polish conditions (sottys was and still is associated with villages). ${ }^{141}$ Sottys' subordination to the wójt (advocatus), and not to the castellan, also fits well with the state of things in Poland, where high courts of German law, headed by wójt (advocatus supremi iudicii), acted as appellate courts with jurisdiction over the sottys, even though the captains (starosta, capitaneus) were occasionally allowed to take part in the proceedings. ${ }^{142}$ On the other hand, the reason for omitting the passage about liability for breaking urban statutes (wilkierze) is unclear; perhaps the author thought that this could be inferred from the general wording of the provision. ${ }^{143}$

\subsection{Summary: The Wawel Variant}

As the discussion above shows, the author of the Działyńscy Codex IV was by no means a mere copyist. His work involved a considerable amount of research and editorial autonomy. His base was a Group II text, but he also made use of a Group I manuscript and had knowledge of the text of the Wawel MS (BJ 168). His manuscript has an extraordinary number of features that are unique. Its wide-ranging dependence on Group II, despite some modifications harking back to the Wawel MS and the omission from the Sachsenspiegel of several articles included in the Weichbild, as in MS BJ 168, provide good grounds for treating the Działyńscy Codex IV as an affiliate of the Cracow version rather than a new offshoot of the Weichbild tradition. However, to give due acknowledgement of its connections with the Wawel Ms, the group containing the Działyńscy Codex IV and the Warsaw ms should be called the Wawel variant of the Cracow version. It also owes its individual character to, first, its author's determination and consistency in clearing up the overlaps between the Weichbild and the Sachsenspiegel and, second, to the clearheaded pragmatism of his numerous amendments, which range from substantive modifications of the law and judicial procedure to clarification of the language of legal provisions.

\footnotetext{
140 No. 41.

141 No. 202.

142 No. 208. See Ludwik Łysiak, "Sąd wyższy prawa niemieckiego w Bieczu” [The High Court of German Law in Biecz], Czasopismo Prawno-Historyczne 33/1 (1981), 7-10.

143 No. 5.
} 

Evolution of the Legal Text

The most important outcome of this comparative analysis is the establishment on the basis of compelling evidence that the Latin Weichbild, which was widely used in Poland from the 14th century onwards, can be sorted into two main types, descended from the Sandomierz version and the Cracow version, as well as a group of manuscripts in which elements of both types are combined. It has also been possible identify within the Cracow version a distinct sub-group, the Wawel variant, with a set of formal characteristics which can be traced to the German-language MS BJ 168, compiled for the High Court of German Law at the Royal Castle of Wawel.

The versio Sandomiriensis is a translation of a German text in which the wording of several provisions is closer to the Constitution of Courts and to another text antecedent to the Wawel MS than to the Cracow MS (BJ 169): the manuscript of the Cracow City Council. Konrad of Sandomierz also supplemented his translation with additions from the Sachsenspiegel and the Magdeburg Legal Instructions for Wroctaw of 1261. The translation is quite faithful to the German text, although there are a considerable number of divergences. It was completed prior to 1359, that is, the year to which the Gniezno Ms, the earliest extant manuscript with the Latin Weichbild of this version, can be dated back. For all we know, the Gniezno manuscript is not an exact copy of the lost archetype. Mikołaj of Cieszyn (or perhaps another copyist whose text Mikołaj of Cieszyn reproduced) made a few amendments which found their way verbatim into the Działyńscy Codex I, and then, to a varying extent, into some other manuscripts. These alterations have parallels in the German texts, which adds more weight to the argument that the evolution of the Latin text proceeded of its own accord.

The numerous divergences in the Silesia-Małopolska compilation from the German Weichbild may well have been the reason why - before 1368 - an anonymous author decided to produce another Latin translation. He made use of Konrad of Sandomierz's translation, but collated its text with his own German base. As a result, in this new translation, a number of articles received completely new wording and contents. Its author also decided to include the provisions of the Constitution of Courts, left out by Konrad of Sandomierz. They had little practical use, but thanks to their inclusion, the new translation was brought into alignment with the German texts of the Silesian-Małopolska compilation. A close comparison of Articles 24, 76, and 87 in the two versions indicates that Cracow version could not be dated earlier than the Sandomierz version. This leads us to the conclusion that the 'doublets' (unnecessary 
repetitions) in the manuscripts of the Cracow version resulted from an imperfect adaptation of the earlier text - or, that the author decided to make do with some clumsiness in order to achieve the greater goal of formal coherence with the German text of the Silesian-Małopolska compilation. However, what gave the Cracow version its distinctive character was not only a reconnection with its German sources, but also the augmentation of the Weichbild with a selection of the Magdeburg ortyle. Whoever thought of combining the ortyle with the Latin Weichbild must have found its Cracow version better suited for that union because of its formal coherence with the German Weichbild, which had been earlier supplemented with the ortyle. The reasons for naming the textual version that evolved away from the versio Sandomiriensis after Cracow could not be clearer: first, the German text with the ortyle descended from the Cracow Ms; and second, the ortyle came from a collection that had been compiled in Cracow. 


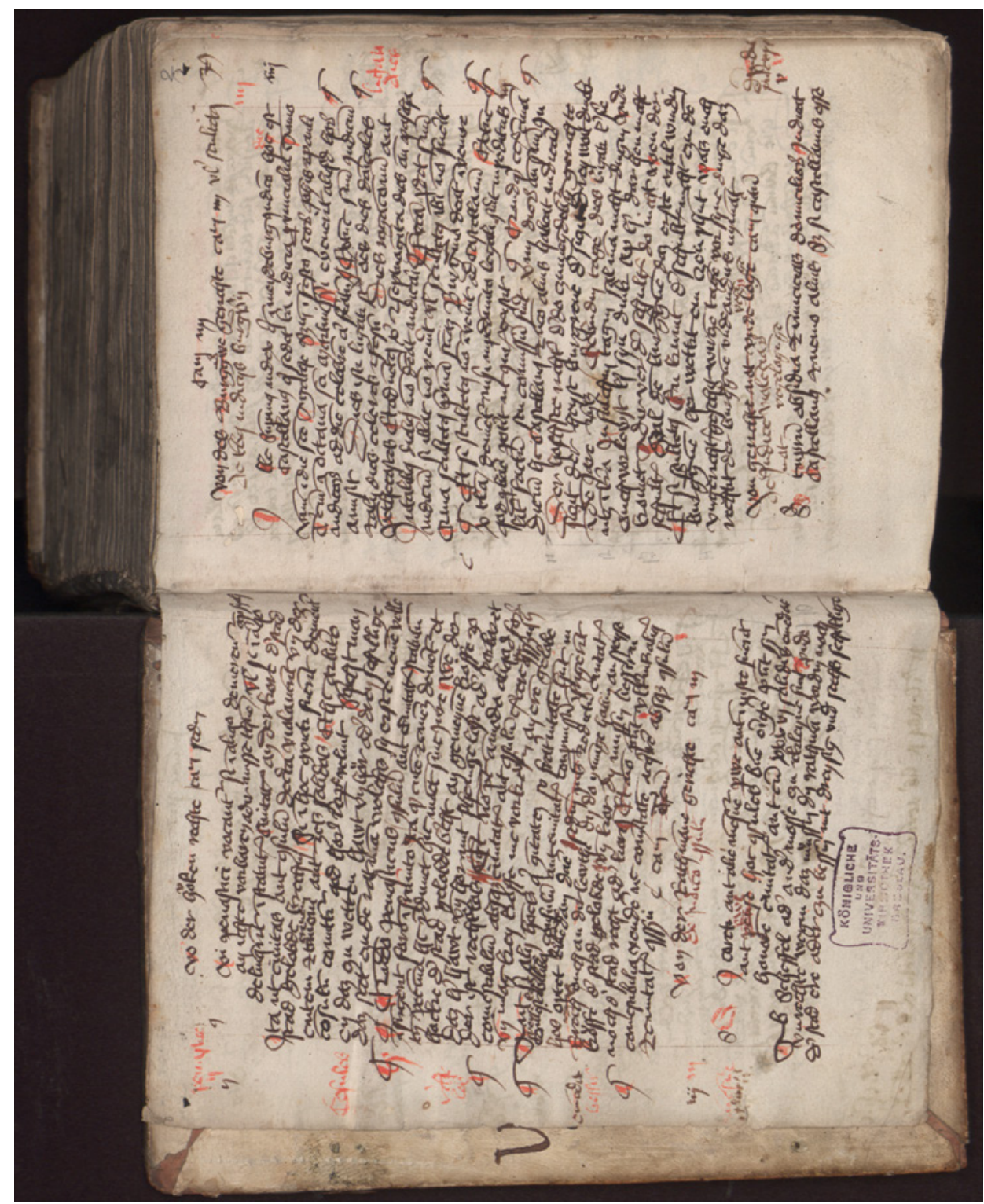

| 


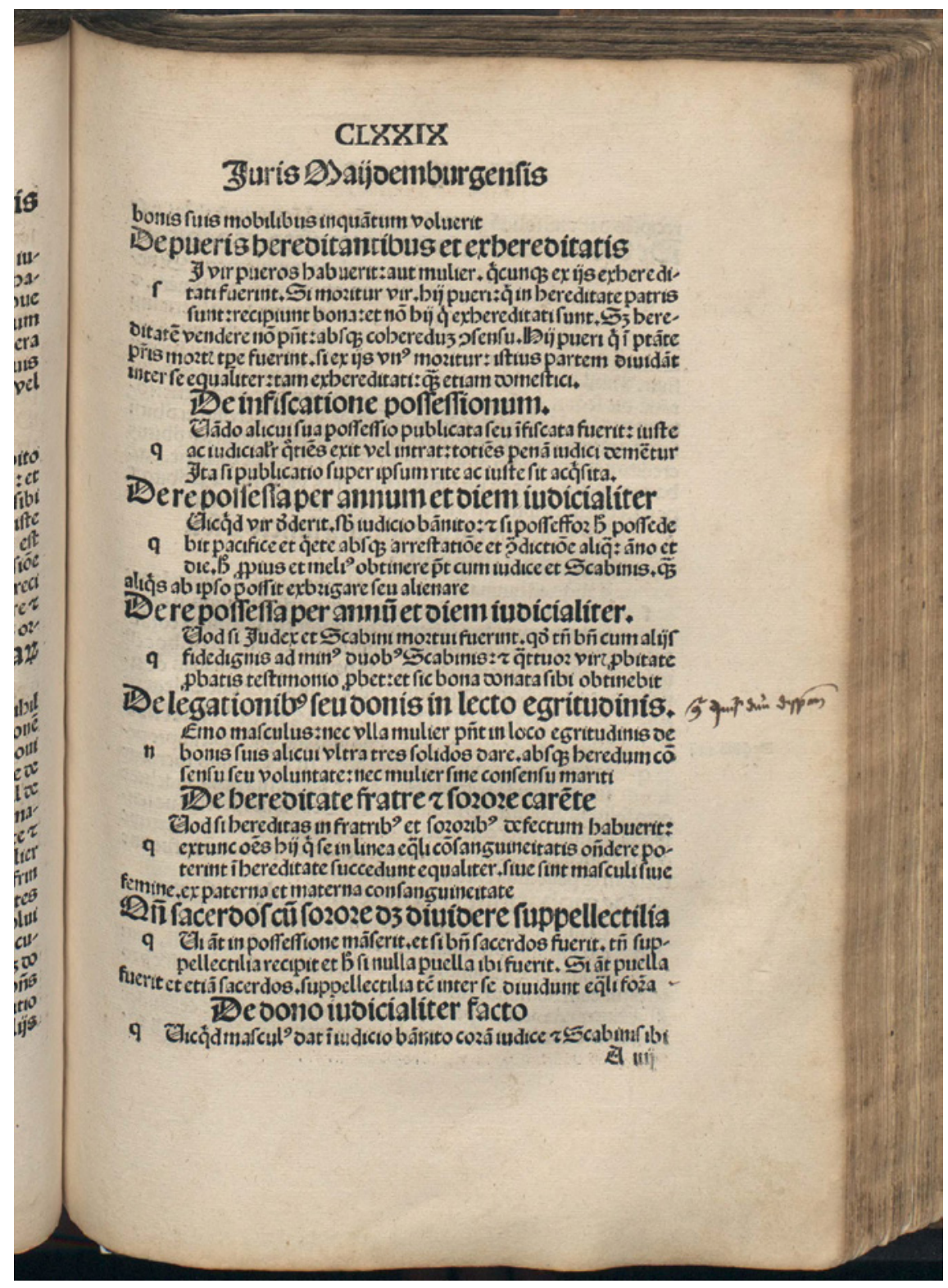

рното 6 Commune Incliti Poloniae Regni privilegium constitutionum et indultuum publicitus decretorum approbatorumque, ed. Jan Łaski (Cracoviae, 1506), f. 179r 